\title{
Palaeoclimatic oscillations in the Pliensbachian (Early Jurassic) of the Asturian Basin (Northern Spain)
}

\author{
Juan J. Gómez ${ }^{1}$, María J. Comas-Rengifo ${ }^{2}$, and Antonio Goy ${ }^{3}$ \\ ${ }^{1}$ Departamento de Estratigrafía, Facultad de Ciencias Geológicas (UCM) and Instituto de Geociencias (CSIC-UCM), \\ 28040 Madrid, Spain \\ ${ }^{2}$ Departamento de Paleontología, Facultad de Ciencias Geológicas (UCM), 28040 Madrid, Spain \\ ${ }^{3}$ Departamento de Paleontología, Facultad de Ciencias Geológicas (UCM) and Instituto de Geociencias (CSIC-UCM), \\ 28040 Madrid, Spain
}

Correspondence to: Juan J. Gómez (jgomez@ucm.es)

Received: 13 July 2015 - Published in Clim. Past Discuss.: 27 August 2015

Revised: 25 April 2016 - Accepted: 26 April 2016 - Published: 20 May 2016

\begin{abstract}
One of the main controversial themes in palaeoclimatology involves elucidating whether climate during the Jurassic was warmer than the present day and if it was the same over Pangaea, with no major latitudinal gradients. There has been an abundance of evidence of oscillations in seawater temperature throughout the Jurassic. The Pliensbachian (Early Jurassic) constitutes a distinctive time interval for which several seawater temperature oscillations, including an exceptional cooling event, have been documented. To constrain the timing and magnitude of these climate changes, the Rodiles section of the Asturian Basin (Northern Spain), a well exposed succession of the uppermost Sinemurian, Pliensbachian and Lower Toarcian deposits, has been studied. A total of 562 beds were measured and sampled for ammonites, for biochronostratigraphical purposes, and for belemnites, to determine the palaeoclimatic evolution through stable isotope studies. Comparison of the recorded latest Sinemurian, Pliensbachian and Early Toarcian changes in seawater palaeotemperature with other European sections allows characterization of several climatic changes that are likely of a global extent. A warming interval partly coinciding with a $\delta^{13} \mathrm{C}_{\text {bel }}$ negative excursion was recorded at the Late Sinemurian. After a "normal" temperature interval, with temperatures close to average values of the Late Sinemurian-Early Toarcian period, a new warming interval containing a short-lived positive $\delta^{13} \mathrm{C}_{\text {bel }}$ peak, developed during the Early-Late Pliensbachian transition. The Late Pliensbachian represents an outstanding cooling interval containing a $\delta^{13} \mathrm{C}_{\text {bel }}$ positive excursion interrupted by
\end{abstract}

a small negative $\delta^{13} \mathrm{C}_{\text {bel }}$ peak. Finally, the Early Toarcian represented an exceptional warming period, which has been pointed out as being responsible for the prominent Early Toarcian mass extinction.

\section{Introduction}

The idea of an equable Jurassic greenhouse climate, $5-10^{\circ} \mathrm{C}$ warmer than the present day, with no ice caps and presenting a low pole-equator temperature gradient, has been proposed in several studies (i.e. Hallam, 1975, 1993; Chandler et al., 1992; Frakes et al., 1992; Rees et al., 1999). Nevertheless, this hypothesis has been challenged by numerous palaeoclimatic studies, mainly based on palaeotemperature calculations making use of the oxygen isotope data from belemnite and brachiopod calcite as a proxy.

Especially relevant are the latest Pliensbachian-Early Toarcian climate changes, which have been documented in many sections from Western Europe (i. e. Sælen et al., 1996; McArthur et al., 2000; Röhl et al., 2001; Schmidt-Röhl et al., 2002; Bailey et al., 2003; Jenkyns, 2003; Rosales et al., 2004; Gómez et al., 2008; Metodiev and Koleva-Rekalova, 2008; Suan et al., 2008, 2010; Dera et al., 2009, 2010, 2011; Gómez and Arias, 2010; García Joral et al., 2011; Gómez and Goy, 2011; Fraguas et al., 2012), as well as in Northern Siberia and in the Artic Region (Zakharov et al., 2006; Nikitenko, 2008; Suan et al., 2011). The close correlation between the severe Late Pliensbachian Cooling and the Early Toarcian Warming events, and the major Early Toarcian mass extinction indi- 

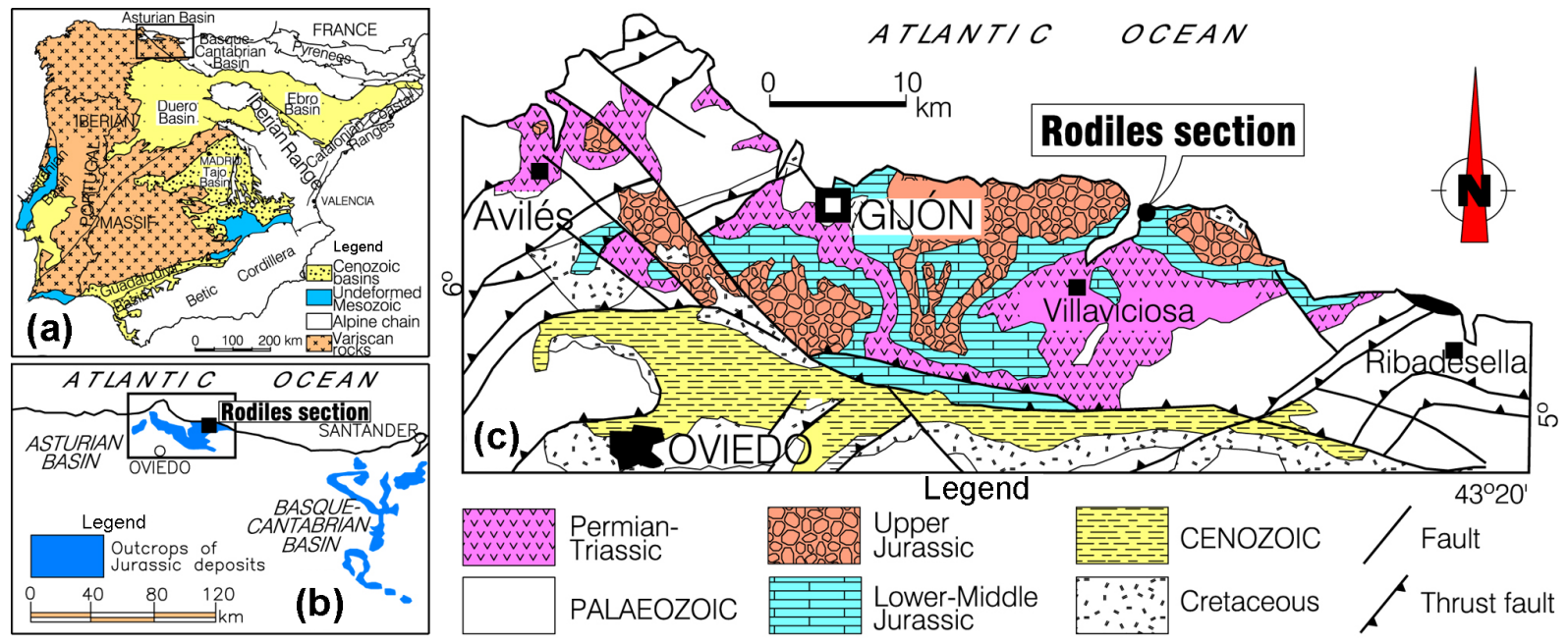

Figure 1. Location maps of the Rodiles section. (a): sketched geological map of Iberia showing the position of the Asturian Basin. (b): outcrops of the Jurassic deposits in the Asturian and the western part of the Basque-Cantabrian basins, and the position of the Rodiles section. (c): geological map of the Asturian Basin showing the distribution of the different geological units and the location of the Rodiles section.

cates that warming was one of the main causes of this faunal turnover (Kemp et al., 2005; Gómez et al., 2008; Gómez and Arias, 2010; García Joral et al., 2011; Gómez and Goy, 2011; Fraguas et al., 2012; Clémence, 2014; Clémence et al., 2015; Baeza-Carratalá et al., 2015).

Nevertheless, with the exception of several sections (Rosales et al., 2004; Korte and Hesselbo, 2011; Suan et al., 2008, 2010), few data have been published on the evolution of seawater palaeotemperatures during the latest Sinemurian and the Pliensbachian, even some more papers studied the climatic changes of parts of the Late Pliensbachian and Early Toarcian (i.e. McArthur et al., 2000; Hesselbo et al., 2000; Jenkyns et al., 2002; van de Schootbrugge et al., 2010; Gómez and Goy, 2011; Armendáriz et al., 2012; Harazim et al., 2013).

The present paper attempts to provide data on the evolution of seawater palaeotemperatures and on changes in carbon isotopes through the Late Sinemurian, Pliensbachian and Early Toarcian (Early Jurassic) and to constrain the timing of the recorded changes through ammonite-based biochronostratigraphy. The data set was obtained from the particularly well-exposed Rodiles section, located in the Asturia's regional autonomy in Northern Spain (Fig. 1). Our results have been correlated with the records obtained in different sections of Europe, showing that these climatic changes, as well as the documented perturbations of the carbon cycle, could be of global, or at least of regional extent at European scale.

\section{Materials and methods}

In the coastal cliffs located northeast of the Villaviciosa village, in the eastern part of the Asturias regional autonomy (Northern Spain) (Fig. 1), the well exposed Upper Sine- murian, Pliensbachian and Lower Toarcian deposits are represented by a succession of alternating lime mudstone to bioclastic wackestone and marls with interbedded black shales belonging to the Santa Mera Member of the Rodiles Formation (Valenzuela, 1988) (Fig. 2). The uppermost Sinemurian and Pliensbachian deposits were studied in the eastern part of the Rodiles Cape and the uppermost Pliensbachian and Lower Toarcian in the western part of the Rodiles Cape (West Rodiles section of Gómez et al., 2008; Gómez and Goy, 2011). Both fragments of the section are referred to here as the Rodiles section (lat. $43^{\circ} 32^{\prime} 22^{\prime \prime}$ long. $5^{\circ} 22^{\prime} 22^{\prime \prime}$ ). Palaeogeographical reconstruction based on comprehensive palaeomagnetic data, performed by Osete et al. (2010), locates the Rodiles section studied at a latitude of approximately $32^{\circ} \mathrm{N}$ for the Hettangian-Sinemurian interval, which is in good agreement with the calculations of Van Hinsbergen et al. (2015) and at a latitude of almost $40^{\circ} \mathrm{N}$ (the current latitude of Madrid) for the Toarcian-Aalenian interval. The section was deposited in an open marine external platform environment with sporadic intervals of oxygen deficiency.

The $110 \mathrm{~m}$ thick section studied, comprising 562 beds, was studied bed by bed. Collected ammonites were prepared and studied following the habitual palaeontological methods (Comas-Rengifo, 1985; Phelps, 1985; Howarth, 2002). The biochronostratigraphy obtained enabled characterization of the standard chronozones and subchronozones established by Elmi et al. (1997) and Page (2003), which are used in the present research.

A total of 191 analyses of stable isotopes were performed on 163 belemnite calcite samples, in order to obtain the primary Late Sinemurian, Pliensbachian and Early Toarcian seawater stable isotope signal, and hence to determine palaeotemperature changes, as well as the variation pattern 


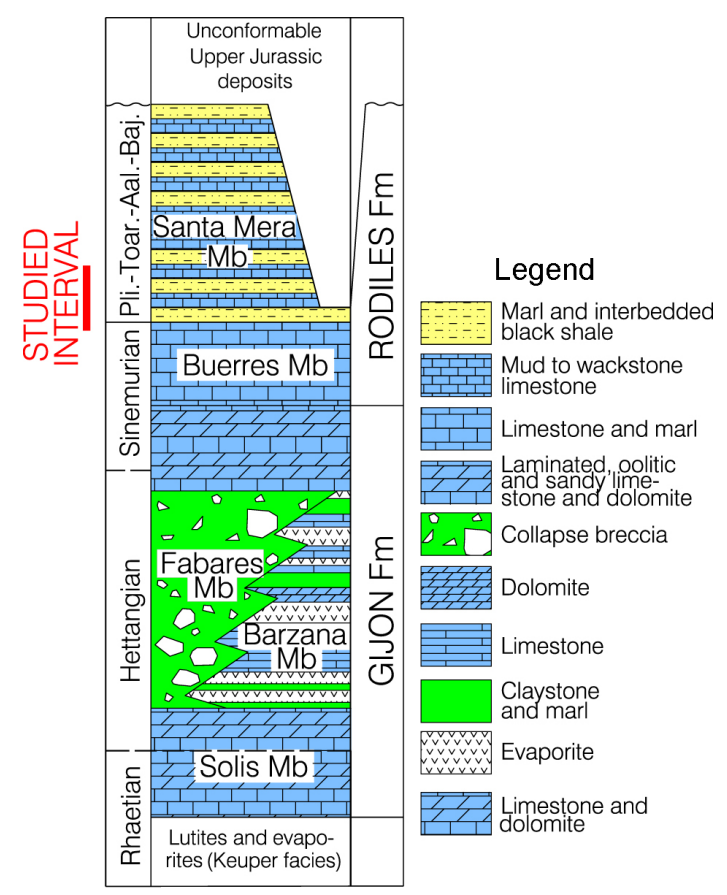

Figure 2. Sketch of the stratigraphical succession of the uppermost Triassic and the Jurassic deposits of the Asturian Basin. The studied interval corresponds to the lower part of the Santa Mera Member of the Rodiles Formation. Pli.= Pliensbachian, Toar. = Toarcian . Aal. $=$ Aalenian. Baj. $=$ Bajocian

of the carbon isotope in the studied time interval. In order to assess possible burial diagenetic alteration of the belemnites, polished samples and thick sections of each belemnite rostrum were prepared. The thick sections were studied under the petrographic and the cathodoluminescence microscope, and only the non-luminescent, diagenetically unaltered portions of the belemnite rostrum were sampled using a microscope-mounted dental drill. Sampling of the luminescent parts such as the apical line and the outer and inner rostrum wall, fractures, stylolites and borings were avoided. Belemnite calcite was processed in the stable isotope labs of Michigan University (USA), with a Finnigan MAT 253 triple collector isotope ratio mass spectrometer. The procedure followed in the stable isotope analysis has been described in Gómez and Goy (2011). Isotope ratios are reported in per mil relative to the standard Peedee belemnite (PDB), presenting a reproducibility better than $0.02 \%$ PDB for $\delta^{13} \mathrm{C}$ and better than $0.06 \%$ PDB for $\delta^{18} \mathrm{O}$.

The seawater palaeotemperature recorded in the oxygen isotopes of the belemnite rostra studied have been calculated using the Anderson and Arthur (1983) equation: $T\left({ }^{\circ} \mathrm{C}\right)=16.0-4.14\left(\delta_{\mathrm{c}}-\delta_{\mathrm{w}}\right)+0.13\left(\delta_{\mathrm{c}}-\delta_{\mathrm{w}}\right)^{2}$ where $\delta_{\mathrm{c}}=$ $\delta^{18} \mathrm{O}$ PDB is the composition of the sample, and $\delta_{\mathrm{w}}=\delta^{18} \mathrm{O}$ SMOW the composition of ambient seawater. Following the recommendations of Shackleton and Kennett (1975), the standard value of $\delta_{\mathrm{w}}=-1 \%$ was used for palaeotempera- ture calculations under non-glacial ocean water conditions. If the presence of permanent ice caps in the poles is demonstrated for some of the intervals studied, value of $\delta_{\mathrm{w}}=0 \% \mathrm{o}$ would be used and consequently calculated palaeotemperatures would increase in the order of $4{ }^{\circ} \mathrm{C}$.

To calculate palaeotemperature, it has been assumed that the $\delta^{18} \mathrm{O}$ values, and consequently the resultant curve, essentially reflect changes in environmental parameters (Sælen et al., 1996; Bettencourt and Guerra, 1999; McArthur et al., 2007; Price et al., 2009; Rexfort and Mutterlose, 2009; Benito and Reolid, 2012; Li et al., 2012; Harazim et al., 2013; Ullmann et al., 2014, Ullmann and Korte, 2015), as the sampled non-luminescent biogenic calcite of the studied belemnite rostra precipitated in equilibrium with the seawater.

\subsection{Reliability of belemnite isotope records}

Discussion of the palaeoecology of belemnites, or the validity of the isotopic data obtained from belemnite calcite for the calculation of palaeotemperatures do not fall within the scope of this research, but the use of belemnite calcite as a proxy is generally accepted and widely used as a reliable tool for palaeothermometry in most of the Mesozoic. However, belemnite palaeoecology constitutes a source of conflicts because, due to the fact that these organisms are extinct, there is a complete lack of understanding of fossil belemnite ecology (Rexfort and Mutterlose, 2009). Belemnites lived as active predators within swimming life habitats. Nevertheless, several authors (Anderson et al., 1994; Mitchell, 2005; Wierzbowski and Joachimiski, 2007) have proposed a bottom-dwelling lifestyle on the basis of oxygen isotope thermometry, similar to modern sepiids which show a nektobenthic mode of life. This is contradicted by the occurrence of various belemnite genera in black shales which lack any benthic or nektobenthic organisms due to the existence of anoxic bottom waters (i.e. the Lower Jurassic Posidonienschiefer, see Rexfort and Mutterlose, 2009), a fact that indicates that belemnites presented a nektonic mode of life rather than a nektobenthic (Mutterlose et al., 2010). As Rexfort and Mutterlose (2009) stated, it is unclear whether isotopic data from belemnites reflect a surface or a deeper water signal, and we are unaware whether the belemnites mode of life changed during ontogeny. Similarly, Li et al. (2012) concluded that belemnites were mobile and experienced a range of environmental conditions during growth; furthermore, these authors stated that some belemnite species inhabited environmental niches that remain unchanged, while other species had a more cosmopolitan lifestyle inhabiting wider environments. To complete the scenario, Mutterlose et al. (2010) suggested different lifestyles (nektonic versus nektobenthic) of belemnite genera as indicated by different shaped guards. Short, thick guards could indicate nektobentic lifestyle, elongated forms fast swimmers, and extremely flattened guards a benthic lifestyle. 
The study by Ullmann et al. (2014) hypothesizes that belemnites (Passaloteuthis) of the Lower Toarcian Tenuicostatum Zone had a nektobenthic lifestyle and once became extinct (as many organisms in the Early Toarcian mass extinction) were substituted by belemnites of the genus Acrocoelites supposedly with a nektonic lifestyle, which these authors attribute to anoxia.

The isotopic studies performed on present-day cuttlefish (Sepia sp.), which are assumed to constitute the group most equivalent to belemnites, reveals that all the specimens (through their $\delta^{18} \mathrm{O}$ signal) perfectly reflect the temperature characteristics of their habitat (Rexfort and Mutterlose, 2009). Also the studies of Bettencourt and Guerra (1999), performed in cuttlebone of Sepia officinalis, conclude that the $\delta^{18} \mathrm{O}$-obtained temperature agreed with changes in seawater temperature, thus supporting the use of belemnites as excellent tools for calculation of palaeotemperatures.

It seems that at least some belemnites could swim through the water column, reflecting average temperature and not necessarily only bottom or surface water temperatures. In any case, rather than single specific values, in the present paper comparisons of average temperatures to define the different episodes of temperature changes are used.

\section{Results}

Ammonite taxa distribution and profiles of the $\delta^{18} \mathrm{O}_{\text {bel }}$, $\delta^{13} \mathrm{C}_{\text {bel }}$ and $\delta^{13} \mathrm{C}_{\text {bulk }}$ values obtained from belemnite calcite have been plotted against the 562 measured beds of the Rodiles section (Fig. 3).

\subsection{Lithology}

The Upper Sinemurian, Pliensbachian and Lower Toarcian deposits of the Rodiles section comprise couplets of bioclastic lime mudstone to wackestone limestone and marls. These limestones occasionally contain bioclastic packstone facies concentrated in rills. Limestones, generally recrystallized to microsparite, are commonly well stratified in beds whose continuity can be followed at the outcrop scale, as well as in outcrops several kilometres apart. However, nodular limestone layers, discontinuous at the outcrop scale, are also present. The base of some carbonates can be slightly erosive, and they are commonly bioturbated, to reach the homogenization stage. Ichnofossils, especially Thalassinoides, Chondrites and Phymatoderma, are also present. Marls, with $\mathrm{CaCO}_{3}$ content generally lower than $20 \%$ (Bádenas et al., 2009,2012 ), are frequently grey coloured, occasionally light grey due to the higher proportion of carbonates, with interbedded black intervals. Locally brown coloured sediments are present, more often in the Upper Sinemurian.

\subsection{Biochronostratigraphy}

The ammonite-based biochronostratigraphy of these deposits in Asturias was performed by Suárez-Vega (1974), and the uppermost Pliensbachian and Toarcian ammonites by Gómez et al. (2008) and by Goy et al. (2010a, b). Preliminary biochronostratigraphy of the Late Sinemurian and the Pliensbachian in some sections of the Asturian Basin has been reported by Comas-Rengifo and Goy (2010), and herein we summarize the result of over 10 years of bed by bed sampling of ammonites in the Rodiles section, which provided a precise time constraint for the climatic events described in this work.

The ammonites collected enabled recognition of all the standard Late Sinemurian, Pliensbachian and Early Toarcian chronozones and subchronozones defined by Elmi et al. (1997) and Page (2003) for Europe. The section is generally expanded and ammonites are sufficiently common to constrain the boundaries of the biochronostratigraphical units. Exceptions are the Taylori-Polymorphus subchronozones that could not be separated, and the CapricornusFigulinum subchronozones of the Davoei Chronozone, partly due to the relatively condensed character of this Chronozone. Most of the recorded species belong to the NW Europe province but some representatives of the Tethysian Realm are also present.

\subsection{Belemnite preservation}

Belemnites in the Rodiles section generally show an excellent degree of preservation (Fig. 4) and none of the prepared samples were rejected, as only the non-luminescent parts of the belemnite rostrum not affected by diagenesis were selected. It has been assumed that the biogenic calcite retains the primary isotopic composition of the seawater and that the belemnite migration, skeletal growth, sampling bias, and vital effects are not the main factors responsible for the variations obtained.

The cross-plot of the $\delta^{18} \mathrm{O}$ against the $\delta^{13} \mathrm{C}$ values (Fig. 5) reveals a cluster-type distribution, showing a negative correlation coefficient $(-0.2)$ and very low covariance $\left(R^{2}=\right.$ $0.04)$, supporting the lack of digenetic overprints in the diagenetically screened belemnite calcite analysed.

\subsection{Carbon isotopes}

The carbon isotopes curve reflects several oscillations throughout the section studied (Fig. 3). A positive $\delta^{13} \mathrm{C}_{\text {bel }}$ shift, showing average values of $1.6 \%$ is recorded from the Late Sinemurian Densinodulum to part of the Macdonnelli subchronozones (from metre 0 to 21 in Fig. 3). From the latest Sinemurian Aplanatum Subchronozone (Raricostatum Chronozone) up to the Early Pliensbachian Valdani Subchronozone of the Ibex Chronozone, average $\delta^{13} \mathrm{C}_{\text {bel }}$ values are $-0.1 \%$, delineating an approximately $1-1.5 \%$ relatively well marked negative excursion (from meter 21 to 57 


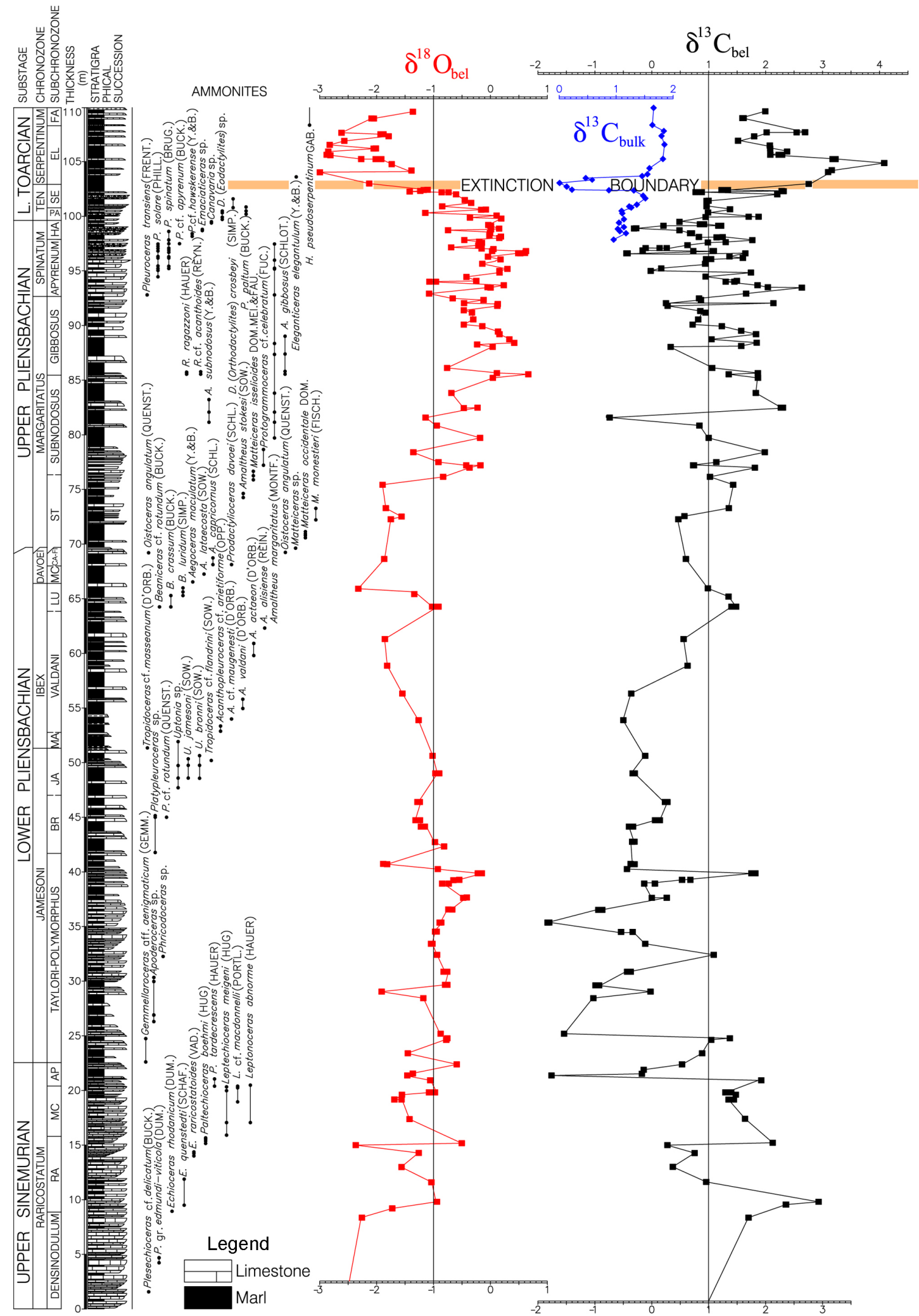

Figure 3. Stratigraphical succession of the Upper Sinemurian, the Pliensbachian and the Lower Toarcian deposits of the Rodiles section, showing the lithological succession, the ammonite taxa distribution, as well as the profiles of the $\delta^{18} \mathrm{O}_{\mathrm{bel}}$ and $\delta^{13} \mathrm{C}_{\mathrm{bel}}$ values obtained from belemnite calcite. $\delta^{18} \mathrm{O}_{\text {bel }}$ and $\delta^{13} \mathrm{C}_{\text {bel }}$ in PDB. Chronozones abbreviations: TEN: Tenuicostatum. Subchronozones abbreviations: RA: Raricostatum. MC: Macdonnelli. AP: Aplanatum. BR: Brevispina. JA: Jamesoni. MA: Masseanum. LU: Luridum. MU: Maculatum. CA: Capricornus. FI: Figulinum. ST: Stokesi. HA: Hawskerense. PA: Paltum. SE: Semicelatum. EL: Elegantulum. FA: Falciferum. 

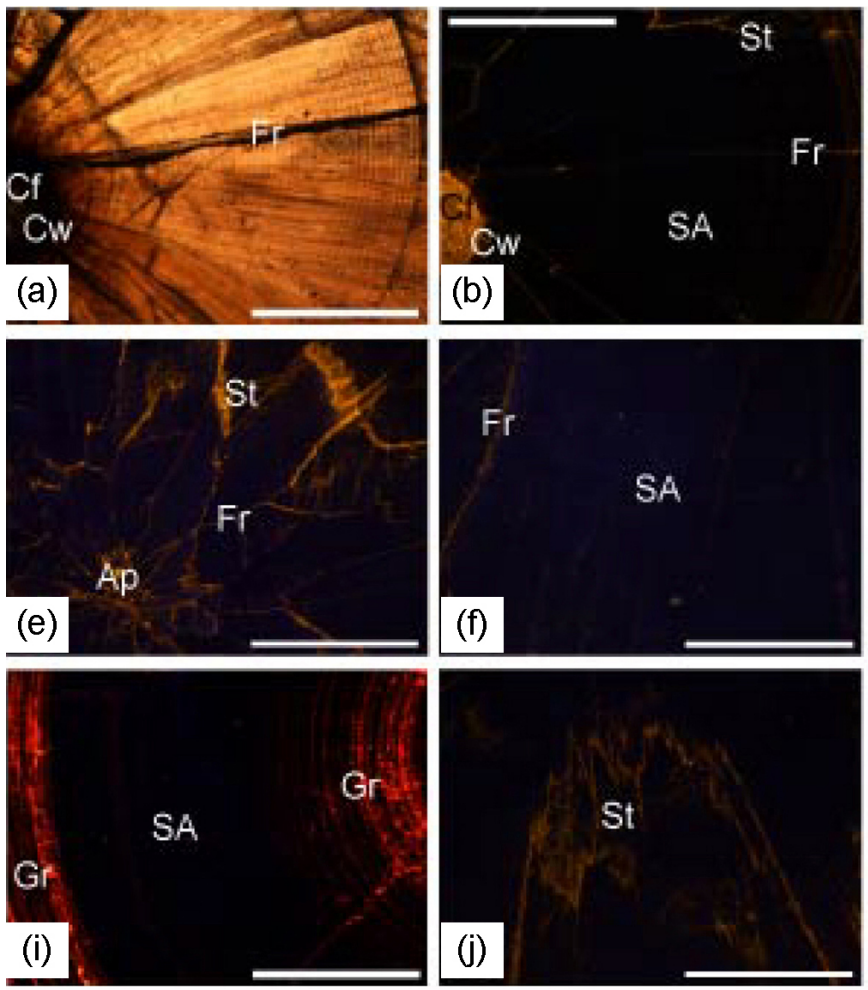
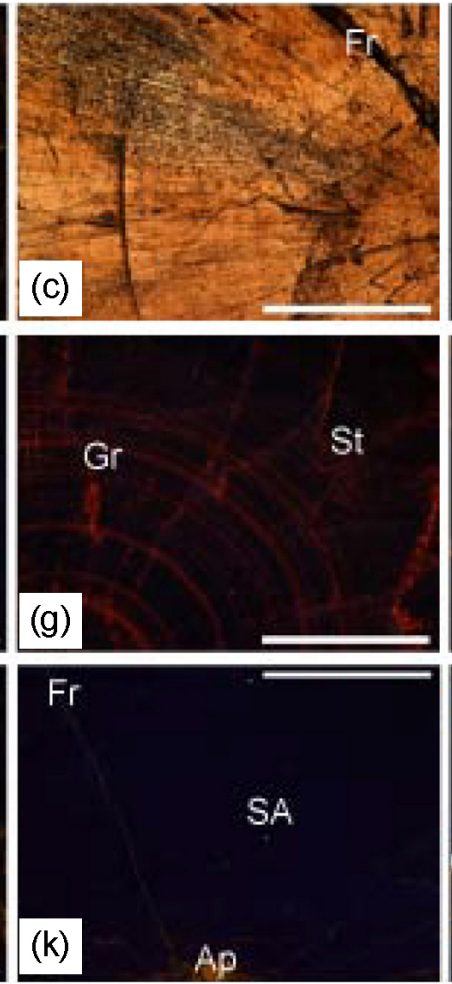
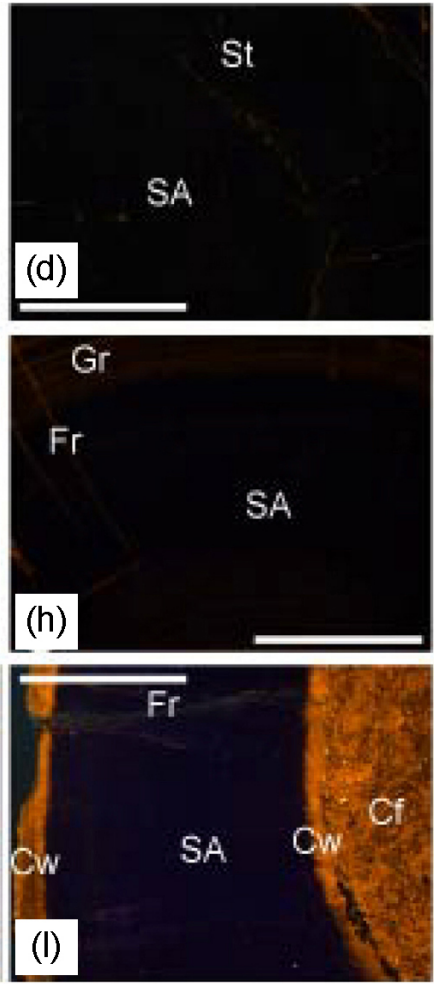

Figure 4. Thick sections photomicrographs of some of the belemnites sampled for stable isotope analysis from the Upper Sinemurian and Pliensbachian of the Rodiles section. The unaltered by diagenesis non-luminescent sampling areas (SA), where the samples have been collected, are indicated. (a) and (b) sample ER 351, Late Sinemurian Raricostatum Chronozone, Aplanatum Subchronozone. (a): optical transmitted light microscope, showing the carbonate deposit filling the alveolous (Cf), the outer rostrum cavum wall (Cw) and fractures (Fr). (b): cathodoluminescence microscope photomicrograph, showing luminescence in the carbonate deposit filling the alveolous (Cf), in the outer rostrum cavum wall $(\mathrm{Cw})$ and in the fractures (Fr). SA represents the unaltered sampling area. (c) and (d): sample ER 337, Early Pliensbachian Jamesoni Chronozone, Taylori-Polymorphus Subchronozones. (c): optical transmitted light microscope, showing fractures (Fr). (d): cathodoluminescence microscope photomicrograph, showing luminescence in stylolites (St). SA is the unaltered sampling area. (e) and (f): Sample ER 589a Early Pliensbachian Margaritatus Chronozone, Subnodosus Subchronozone. (e): cathodoluminescence microscope, showing luminescence in the apical line (Ap), fractures (Fr) and stylolites (St). This area of the section was not suitable for sampling. (f): another field of the same sample as (h) showing scarce fractures (Fr) and the unaltered non-luminescent sampled area (SA). (g) and (h): Sample ER 549a, Late Pliensbachian Margaritatus Chronozone, Stokesi Subchronozone. (g): cathodoluminescence microscope showing luminescent growth rings (Gr) and stylolites ( $\mathrm{St}$ ). Area not suitable for sampling. (h): cathodoluminescence microscope photomicrograph, of the same sample as (g), showing luminescent growth rings (Gr) and fractures (Fr), with unaltered sampling area (SA). (i): sample ER 555 Late Pliensbachian Margaritatus Chronozone, Stokesi Subchronozone. Cathodoluminescence microscope photomicrograph showing luminescent growth rings $(\mathrm{Gr})$ and the unaltered sampling area (SA). (j) and (k): sample ER 623 Late Pliensbachian Spinatum Chronozone, Apyrenum Subchronozone. (j): cathodoluminescence microscope photomicrograph showing luminescent stylolites (St). (k): another field of the same sample as (j) showing luminescence in the apical line (Ap) and fractures (Fr) as well as the non-luminescent unaltered sampling area (SA). (l): sample ER 597, Late Pliensbachian Margaritatus Chronozone, Gibbosus Subchronozone. Cathodoluminescence microscope photomicrograph showing luminescent carbonate deposit filling the alveolous $(\mathrm{Cf})$, the outer and inner rostrum cavum wall $(\mathrm{Cw})$, the fractures $(\mathrm{Fr})$ and the non-luminescent sampling area (SA). Scale in bar for all the photomicrographs: $1 \mathrm{~mm}$.

in Fig. 3). In the late Ibex and in the Davoei chronozones, the $\delta^{13} \mathrm{C}_{\text {bel }}$ curve records background values of around $1 \%$, with a positive excursion at the latest Ibex Chronozone and the earliest Davoei Chronozone (from meter 62 to 67 in Fig. 3).

At the Late Pliensbachian the $\delta^{13} \mathrm{C}_{\text {bel }}$ values tend to outline a slightly positive excursion (from meter 71 to 97 in Fig. 3), interrupted by a small negative peak in the latest Spinatum Chronozone (from meter 98 to 103 in Fig. 3). The Early Toarcian curve reflects the presence of a positive $\delta^{13} \mathrm{C}_{\text {bel }}$ trend which develops above the stratigraphical levels represented herein, up to the Middle Toarcian Bifrons Chronozone (Gómez et al., 2008) and a negative excursion recorded in bulk carbonates samples.

\subsection{Oxygen isotopes}

The $\delta^{18} \mathrm{O}_{\text {bel }}$ values show the presence of several excursions throughout the Late Sinemurian to the Early Toarcian 


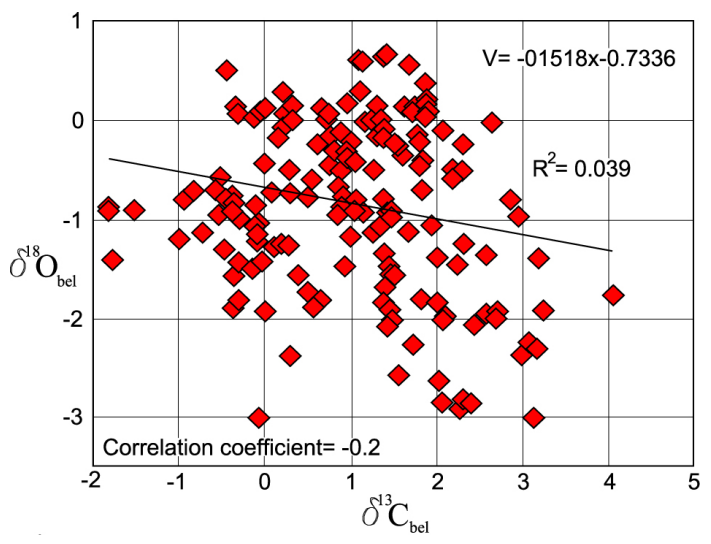

Figure 5. Cross-plot of the $\delta^{18} \mathrm{O}_{\text {bel }}$ against the $\delta^{13} \mathrm{C}_{\mathrm{bel}}$ values obtained in the Rodiles section showing a cluster type of distribution. All the assayed values are within the rank of normal marine values, and the correlation coefficient between both stable isotope values is negative, supporting the lack of diagenetic overprints in the sampled belemnite calcite. $\delta^{18} \mathrm{O}_{\text {bel }}$ and $\delta^{13} \mathrm{C}_{\text {bel }}$ in PDB.

(Fig. 3). From the Late Sinemurian to the earliest Pliensbachian interval, a negative excursion of around $1 \%$, showing values generally below $-1 \%$ o(from meter 0 to 18 in Fig. 3) with peak values up to $-3 \%$ o has been recorded in Sinemurian samples located immediately below the stratigraphic column represented in Fig. 3. In most of the Early Pliensbachian Jamesoni and the earliest part of the Ibex chronozones, $\delta^{18} \mathrm{O}_{\text {bel }}$ values are quite stable, around $-1 \%$ o (from meter 18 to 56 in Fig. 3), but another negative excursion of approximately $1-1.5 \%$, with peak values up to $-1.9 \%$ o, develops along most of the Early Pliensbachian Ibex and Davoei chronozones, extending up to the base of the Late Pliensbachian Margaritatus Chronozone (from meter 56 to 76 in Fig. 3). Most of the Late Pliensbachian and the earliest Toarcian are characterized by the presence of a significant change. In this interval (from meter 76 to 103 in Fig. 3) a positive excursion in the order of $1.5 \% \circ \delta^{18} \mathrm{O}_{\text {bel }}$, with frequent values of around $0 \%$, and positive values up to $0.7 \%$, were assayed. The oxygen isotopes recorded a new change in its tendency in the Early Toarcian, where a prominent $\delta^{18} \mathrm{O}_{\text {bel }}$ negative excursion, about $1.5-2 \%$ with values up to $-3 \%$, has been verified (from meter 103 to 110 in Fig. 3).

\section{Discussion}

The isotope curves obtained in the Upper Sinemurian, Pliensbachian and Lower Toarcian section of the Asturian Basin have been correlated with other successions of a similar age, in order to evaluate whether the environmental features recorded present a local or possible global extent. In order to correlate a more homogeneous data set, we only employed the isotopic results obtained by other authors from belemnite calcite and exceptionally from brachiopod calcite.

\subsection{Updated stratigraphy}

The detailed biostratigraphical analysis, based on the succession of the Pliensbachian ammonoids assemblages allowed construction of a scale of reference that has facilitated the location of the different palaeoclimatic events recognized in the present research.

The five biochronozones of the standard scale constituting the Pliensbachian of the Subboreal/NW Europe Province (Dommergues et al., 1997; Page, 2003) have been recognized in the Rodiles section. For the first time, these biochronozones have been subdivided into 14 subchronozones whose boundaries have been corrected in many cases with respect to previous studies. In most cases these boundaries have now been established with a low margin of uncertainty.

With regard to previous research (Suárez-Vega, 1974; Comas-Rengifo and Goy, 2010) the Taylori and Brevispina subchronozones of the Early Pliensbachian have been characterized in this study for the first time, and the boundary between the Valdani and the Luridum subchronozones, usually difficult to distinguish in the Asturian Basin, has been clearly recognized. In the Late Pliesbachian, where the record of Amaltheidae is quite complete, the subchronozone Apyrenum of the Spinatum Chronozone has been characterized and the boundary between the Subnodosus and Gibbosus subchronozones has been precisely established.

\subsection{Carbon isotope curve}

The $\delta^{13} \mathrm{C}_{\text {bel }}$ carbon isotope excursions (CIEs) found in the Asturian Basin, can be followed in other sections across Western Europe (Fig. 6). The Late Sinemurian positive CIE was also recorded in the Cleveland Basin of the UK by Korte and Hesselbo (2011) and in the $\delta^{13} \mathrm{C}_{\text {org }}$ data of the Wessex Basin of southern UK by Jenkyns and Weedon (2013).

The Early Pliensbachian $\delta^{13} \mathrm{C}_{\text {bel }}$ negative excursion extending from the Raricostatum Chronozone of the latest Sinemurian to the Early Pliensbachian Jamesoni and part of the Ibex chronozones (Fig. 6), correlates with the lower part of the $\delta^{13} \mathrm{C}_{\text {bel }}$ negative excursion reported by Armendáriz et al. (2012) in another section of the Asturian Basin. Similarly, the $\delta^{13} \mathrm{C}_{\text {bel }}$ curve obtained by Quesada et al. (2005) in the neighbouring Basque-Cantabrian Basin shows the presence of a negative CIE in a similar stratigraphical position. In the Cleveland Basin in the UK, the studies on the SinemurianPliensbachian deposits conducted by Hesselbo et al. (2000), Jenkyns et al. (2002) and Korte and Hesselbo (2011) reflect the presence of this Early Pliensbachian $\delta^{13} \mathrm{C}_{\text {bel }}$ decrease in values. In the Peniche section of the Lusitanian Basin of Portugal, this negative CIE was also recorded by Suan et al. (2010) in brachiopod calcite, and in bulk carbonates in Italy (Woodfine et al., 2008; Francheschi et al., 2014). The 


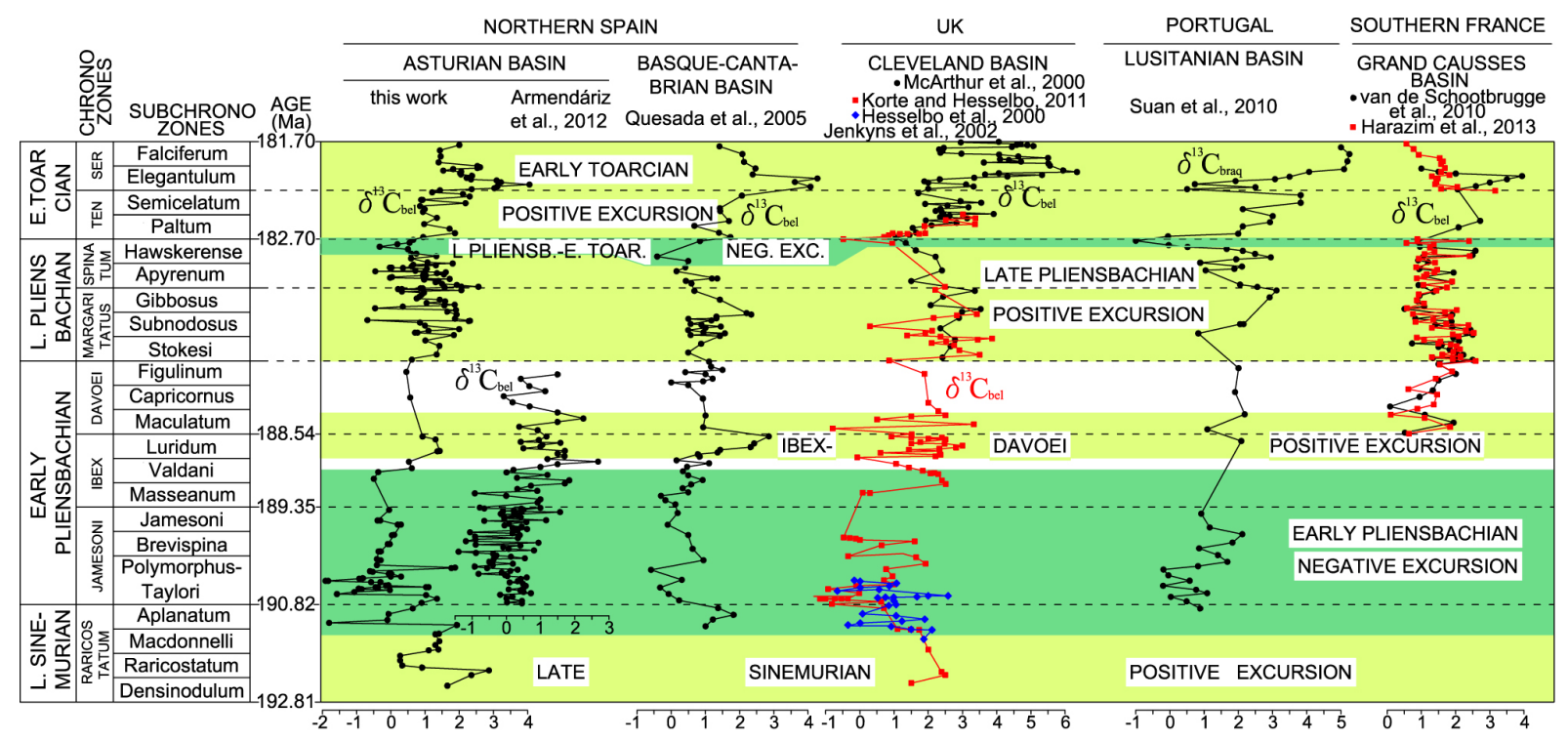

Figure 6. Correlation chart of the belemnite calcite-based $\delta^{13} \mathrm{C}$ sketched curves across Western Europe. The earliest isotopic event is the Late Sinemurian $\delta^{13} \mathrm{C}$ positive excursion, followed by the Early Pliensbachian negative excursion and the Ibex-Davoei positive peak. The Late Pliensbachian $\delta^{13} \mathrm{C}$ positive excursion is bounded by a $\delta^{13} \mathrm{C}$ negative peak, located around the Pliensbachian-Toarcian boundary. A significant $\delta^{13} \mathrm{C}$ positive excursion is recorded in the Early Toarcian. $\delta^{13} \mathrm{C}_{\text {bel }}$ values in PDB. Chronozones abbreviations: TEN: Tenuicostatum. SER: Serpentinum. Ages (Ma) after Ogg and Hinnov (2012).

magnitude of approximately $1.5-2 \%$ of this negative excursion appears to be quite consistent across the different European localities.

Korte and Hesselbo (2011) pointed out that the Early Pliensbachian $\delta^{13} \mathrm{C}$ negative excursion seems to be global in character, resulting from the injection of isotopically light carbon from some remote source, such as methane from clathrates, wetlands, or thermal decomposition, thermal metamorphism or decomposition of older organic-rich deposits. However, none of these possibilities has yet been documented.

Higher in the section, the $\delta^{13} \mathrm{C}$ values are relatively uniform, except for a thin interval, around the Early Pliensbachian Ibex-Davoei zonal boundary, where a small positive excursion (the Ibex-Davoei positive excursion, previously mentioned by Rosales et al., 2001 and by Jenkyns et al., 2002) can be observed in most of the $\delta^{13} \mathrm{C}$ curves summarized in Fig. 6, as well as in the carbonates of the Portuguese Lusitanian Basin (Silva et al., 2011).

The next CIE involves a positive excursion of around 1.5$2 \%$, well recorded in all the correlated Upper Pliensbachian sections (the Late Pliensbachian positive excursion in Fig. 6) and in bulk carbonates of the Lusitanian Basin (Silva et al., 2011; Silva and Duarte, 2015) and in the Apennines of Central Italy (Moretinni et al., 2002). This CIE also partly coincides with the $\delta^{13} \mathrm{C}_{\text {org }}$ reported by Caruthers et al. (2014) in western North America. Around the Pliensbachian-Toarcian boundary, a negative $\delta^{13} \mathrm{C}$ peak is once again recorded (Fig. 6). This narrow excursion was described by Hesselbo et al. (2007) in bulk rock samples in Portugal, and tested by Suan et al. (2010) in the same basin and extended to the Yorkshire (UK) by Littler et al. (2010) and by Korte and Hesselbo (2011). If this perturbation of the carbon cycle is global, as Korte and Hesselbo (2011) pointed out, it could correspond with the negative $\delta^{13} \mathrm{C}$ peak recorded in the upper part of the Spinatum Chronozone in the Asturian Basin (present paper); with the negative $\delta^{13} \mathrm{C}$ peak reported by Quesada et al. (2005) in the same stratigraphical position in the Basque-Cantabrian Basin, and with the $\delta^{13} \mathrm{C}$ negative peak reported by van de Schootbrugge et al. (2010) and Harazim et al. (2013) in the French Grand Causses Basin.

Finally, the Early Toarcian is characterized by a prominent $\delta^{13} \mathrm{C}$ positive excursion that has been detected in all the sections considered herein, as well as in some South American (Al-Suwaidi et al., 2010) and Northern African (Bodin et al., 2010) sections. This positive CIE is interrupted by a negative excursion of approximately $1 \% \circ \delta^{13} \mathrm{C}_{\text {bulk }}$ located around the Tenuicostatum-Serpentinum zonal boundary.

The origin of the positive excursion has been interpreted by some authors as the response of water masses to excess and rapid burial of large amounts of organic carbon rich in ${ }^{12} \mathrm{C}$, which led to enrichment in ${ }^{13} \mathrm{C}$ of the sediments (Jenkyns and Clayton, 1997; Schouten et al., 2000). Other authors ascribe the origin of this positive excursion to the removal from the oceans of large amounts of isotopically light carbon as organic matter into black shales or methane hydrates, resulting from ebullition of isotopically 
heavy $\mathrm{CO}_{2}$, generated by methanogenesis of organic-rich sediments (McArthur et al., 2000).

Although $\delta^{13} \mathrm{C}$ positive excursions are difficult to account for (Payne and Kump, 2007), it seems that this positive CIE cannot necessarily be the consequence of the widespread preservation of organic-rich facies under anoxic waters, as no anoxic facies are present in the Spanish Lower Toarcian sections (Gómez and Goy, 2011). Modelling of the CIEs performed by Kump and Arthur (1999) shows that $\delta^{13} \mathrm{C}$ positive excursions can also be due to an increase in the rate of phosphate or phosphate and inorganic carbon delivery to the ocean, and that large positive excursions in the isotopic composition of the ocean can also result from an increase in the proportion of carbonate weathering relative to organic carbon and silicate weathering. Other authors argue that an increase of $\delta^{13} \mathrm{C}$ in bulk organic carbon may reflect a massive expansion of marine archaea bacteria that do not isotopically discriminate in the type of carbon they use, giving rise to positive $\delta^{13} \mathrm{C}$ shifts (Kidder and Worsley, 2010).

The origin of the Early Toarcian $\delta^{13} \mathrm{C}$ negative excursion has been explained by several papers as resulting from the massive release of large amounts of isotopically light $\mathrm{CH}_{4}$ from the thermal dissociation of gas hydrates. Hesselbo et al. (2000, 2007), Cohen et al. (2004) and Kemp et al. (2005), associated it with the massive release of gas methane linked with the intrusion of the Karoo-Ferrar large igneous province onto coalfields, as proposed by McElwain et al. (2005) or with the contact metamorphism by dykes and sills related to the Karoo-Ferrar igneous activity into organic-rich sediments (Svensen et al., 2007).

Martinez and Dera (2015) proposed the presence of fluctuations in the carbon cycle during the Jurassic and Early Cretaceous, resulting from a cyclicity of $\sim 9$ My linked to a great eccentricity cycle, amplified by cumulative sequestration of organic matter. Nevertheless, this $\sim 9$ My cycle has not been evidenced in the Pliensbachian deposits of several parts of the World (Ikeda and Tada, 2013, 2014) and cannot be evidenced in the Pliensbachian deposits of the Asturian Basin either. The disruption of this cyclicity recorded during the Pliensbachian could be linked to chaotic behaviour in the solar system (Martinez and Dera, 2015) possibly due to the chaotic transition in the Earth-Mars resonance (Ikeda and Tada, 2013). Data from Japan suggest that this disruption, which developed from the Hettangian to the Pliensbachian (Ikeda and Tada, 2013, 2014) was possibly linked to the massive injection of $\mathrm{CO}_{2}$ from the eruptions of the Central Atlantic Magmatic Province to the Karoo-Ferrar eruptions (Prokoph et al., 2013) which destabilized the carbon fluxes, reducing or dephasing the orbital imprint in the $\delta^{13} \mathrm{C}$ over millions of years (Martinez and Dera, 2015).

\subsection{Oxygen isotope curves and seawater palaeotemperature oscillations}

Seawater palaeotemperature calculation from the $\delta^{18} \mathrm{O}$ values obtained reveals the occurrence of several isotopic events corresponding to relevant climatic oscillations across the latest Sinemurian, the Pliensbachian and the Early Toarcian (Fig. 7). Some of these climatic changes could be of global extent. In terms of seawater palaeotemperature, five intervals can be distinguished. The earliest interval of these corresponds to a warming period developed from the Late Sinemurian up to the earliest Pliensbachian. Most of the Early Pliensbachian is represented by a period of "normal" temperature, close to the average palaeotemperatures of the interval studied. A new warming period is recorded in the EarlyLate Pliensbachian transition, and the Late Pliensbachian is represented by an important cooling interval. Finally the Early Toarcian coincides with a severe (super)warming interval, linked to the important Early Toarcian mass extinction (Gómez and Arias, 2010; García Joral et al., 2011; Gómez and Goy, 2011; Fraguas et al., 2012; Clémence, 2014; Clémence et al., 2015; Baeza-Carratalá et al., 2015). The average palaeotemperature of the latest Sinemurian, Pliensbachian (palaeolatitude of $32^{\circ} \mathrm{N}$ ) and Early Toarcian (palaeolatitude of $40^{\circ} \mathrm{N}$ ), calculated from the $\delta^{18} \mathrm{O}$ values obtained from belemnite calcite in the present study, is $15.6^{\circ} \mathrm{C}$. As mentioned above, some belemnites could swim through the water column, and the palaeotemperatures calculated do not necessarily correspond only with the temperatures of the bottom or surface waters, but also the average temperature.

\subsubsection{The Late Sinemurian Warming}

The earliest isotopic event is a $\delta^{18} \mathrm{O}$ negative excursion that develops from the Late Sinemurian Raricostatum Chronozone, up to the earliest Pliensbachian Jamesoni Chronozone. The average palaeotemperature calculated from the $\delta^{18} \mathrm{O}$ belemnite samples collected below the part of the Late Sinemurian Raricostatum Chronozone represented in Fig. 7 was $19.6^{\circ} \mathrm{C}$. This temperature increases to $21.5^{\circ} \mathrm{C}$ in the lower part of the Raricostatum Chronozone (Densinodulum Subchronozone), and progressively decreases throughout the latest Sinemurian and earliest Pliensbachian. In the Raricostatum Subchronozone, the average temperature calculated is $18.7^{\circ} \mathrm{C}$; in the Macdonnelli Subchronozone the average temperature is $17.5^{\circ} \mathrm{C}$ and the average value of $16.7^{\circ} \mathrm{C}$, closer to the average temperature of the studied interval, is not reached until the latest Sinemurian Aplanatum Subchronozone and the earliest Pliensbachian Taylori-Polymorphus subchronozones. All these values delineate a warming interval mainly developed in the Late Sinemurian (Figs. 7, 8) in which the general trend involves a decrease in palaeotemperature from the Late Sinemurian to the earliest Pliensbachian.

The Late Sinemurian Warming interval is also recorded in the Cleveland Basin in the UK (Hesselbo et al., 2000; Ko- 


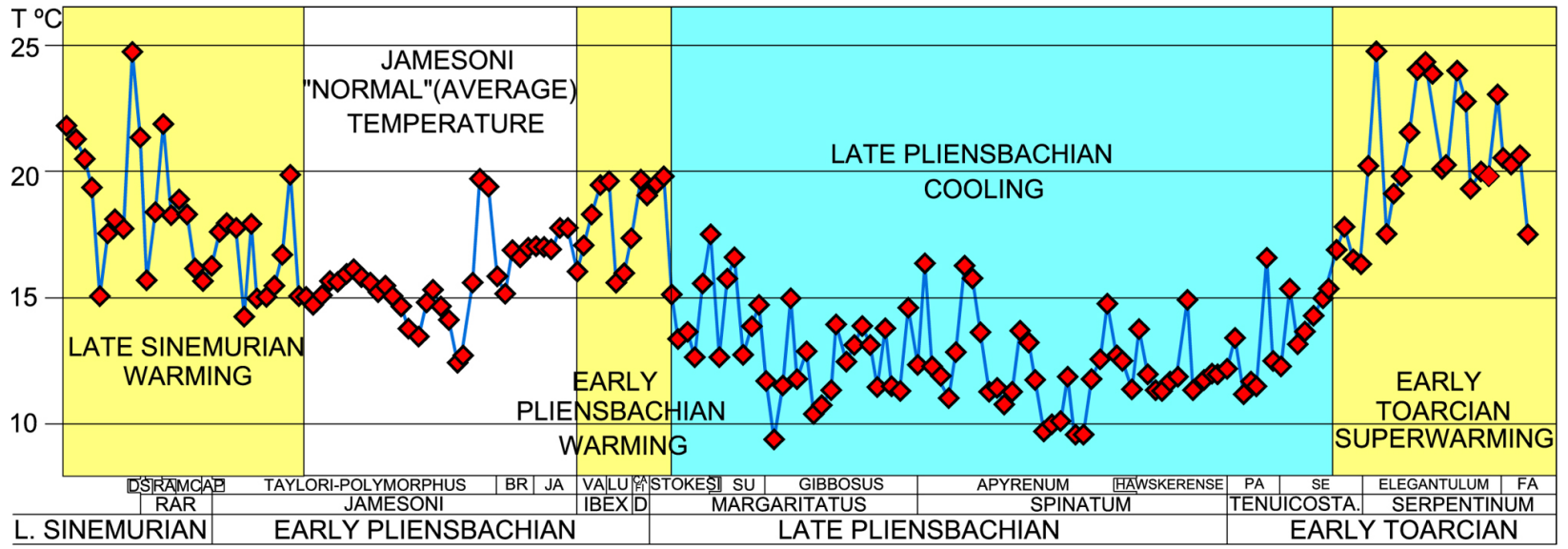

Figure 7. Curve of seawater palaeotemperatures of the Late Sinemurian, Pliensbachian and Early Toarcian, obtained from belemnite calcite in the Rodiles section of Northern Spain. Two warming intervals corresponding to the Late Sinemurian and the Early Pliensbachian are followed by an important cooling interval, developed at the Late Pliensbachian, as well as a (super)warming event recorded in the Early Toarcian. Chronozones abbreviations: RAR: Raricostatum. D: Davoei. TENUICOSTA.: Tenuicostatum. Subchronozones abbreviations: DS: Densinodulum. RA: Raricostatum. MC: Macdonnelli. AP: Aplanatum. BR: Bevispina. JA: Jamesoni. VA: Valdani. LU: Luridum. CA: Capricornus. FI: Figulinum. SU: Subnodosus. PA: Paltum. SE: Semicelatum. FA: Falciferum.

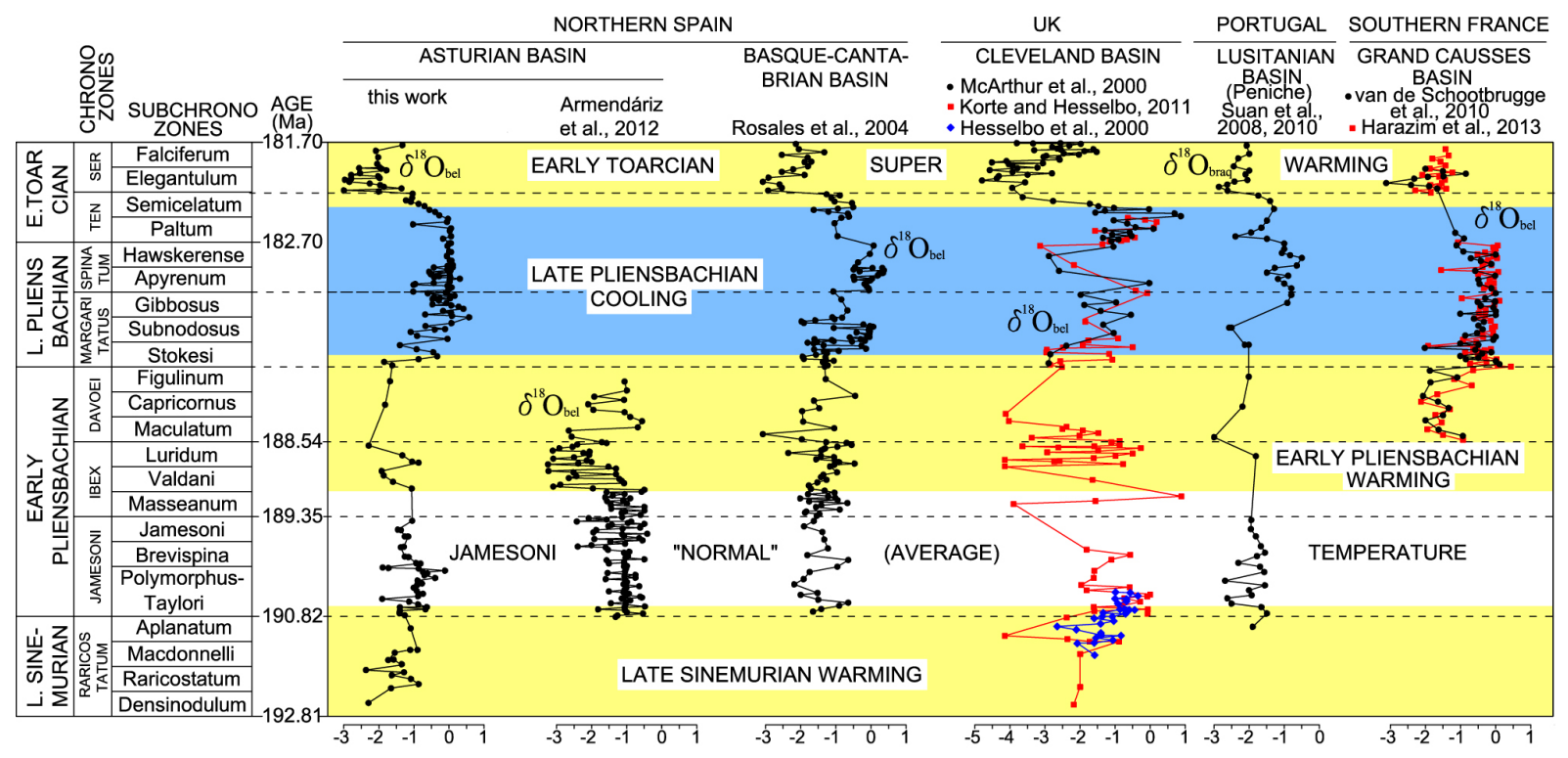

Figure 8. Correlation chart of the belemnite calcite-based $\delta^{18} \mathrm{O}$ sketched curves obtained in different areas of Western Europe. Several isotopic events along the latest Sinemurian, Pliensbachian and Early Toarcian can be recognized. The earliest event is a $\delta^{18} \mathrm{O}$ negative excursion corresponding to the Late Sinemurian Warming. After an interval of "normal" $\delta^{18} \mathrm{O}$ values developed in most of the Jamesoni Chronozone and the earliest part of the Ibex Chronozone, another $\delta^{18} \mathrm{O}$ negative excursion was developed in the Ibex, Davoei and earliest Margaritatus chronozones, representing the Early Pliensbachian Warming interval. A main $\delta^{18} \mathrm{O}$ positive excursion is recorded at the Late Pliensbachian and the earliest Toarcian in all the correlated localities, representing the important Late Pliensbachian Cooling interval. Another prominent $\delta^{18} \mathrm{O}$ negative shift is recorded in the Early Toarcian. Values are progressively more negative in the Tenuicostatum Chronozone and suddenly decrease around the Tenuicostatum-Serpentinum zonal boundary, delineating the Early Toarcian $\delta^{18} \mathrm{O}$ negative excursion which represents the Early Toarcian (super)Warming interval. $\delta^{18} \mathrm{O}_{\text {bel }}$ values in PDB. Ages (Ma) after Ogg and Hinnov (2012).

rte and Hesselbo, 2011). The belemnite-based $\delta^{18} \mathrm{O}$ values obtained by these authors are in the order of -1 to $-3 \%$, with peak values lower than $-4 \%$. This represents a range of palaeotemperatures normally between 16 and $24^{\circ} \mathrm{C}$ with peak values of up to $29^{\circ} \mathrm{C}$, which are not compatible with a cooling interval, but rather with a period of warming. 
The Late Sinemurian warming coincides only partly with the Early Pliensbachian $\delta^{13} \mathrm{C}$ negative excursion, located near the stage boundary (Fig. 6). Consequently, this warming cannot be fully interpreted as the consequence methane release from clathrates, wetlands or decomposition of older organic-rich sediments, as interpreted by Korte and Hesselbo (2011) because only a small portion of both excursions are coincident.

\subsubsection{The "normal" temperature in the Early Pliensbachian Jamesoni Chronozone interval}

Following the Late Sinemurian Warming, $\delta^{18} \mathrm{O}$ values are around $-1 \%$ reflecting average palaeotemperatures of approximately $16^{\circ} \mathrm{C}$ (Fig. 7). This Early Pliensbachian interval of "normal" (average) temperature develops in most of the Jamesoni Chronozone and in the base of the Ibex Chronozone (Fig. 8). In the Taylori-Polymorphus chronozones, average temperature is $15.7^{\circ} \mathrm{C}$, in the Brevispina Subchronozone it is $16.4{ }^{\circ} \mathrm{C}$, and in the Jamesoni Subchronozone 17. $2^{\circ} \mathrm{C}$. Despite exhibiting more variable data, this interval was also recorded in other sections of the Asturian Basin (Fig. 8) by Armendáriz et al. (2012), and relatively uniform values were also recorded in the Basque-Cantabrian Basin of Northern Spain (Rosales et al., 2004) and in the Peniche section of the Portuguese Lusitanian Basin (Suan et al., 2008, 2010). Belemnite calcite-based $\delta^{18} \mathrm{O}$ values published by Korte and Hesselbo (2011) are quite scattered, oscillating between $\sim 1$ and $\sim-4.5 \%$ (Fig. 8 ).

\subsubsection{The Early Pliensbachian Warming interval}

Most of the Early Pliensbachian Ibex Chronozone and the base of the Late Pliensbachian are dominated by a negative excursion ranging from 1 to $1.5 \% \circ \delta^{18} \mathrm{O}$, representing an increase in palaeotemperature, which marks a new warming interval. An average value of $18.2^{\circ} \mathrm{C}$ with a peak value of $19.7^{\circ} \mathrm{C}$ was reached in the Rodiles section (Fig. 7). This increase in temperature partly co-occurs with the latest part of the Early Pliensbachian $\delta^{13} \mathrm{C}$ negative excursion.

The Early Pliensbachian Warming interval is also well marked in other sections of Northern Spain (Fig. 8) such as the Asturian Basin (Armendáriz et al., 2012) and the BasqueCantabrian Basin (Rosales et al., 2004), where peak values of around $25^{\circ} \mathrm{C}$ were reached. The increase in seawater temperature is also registered in the Southern France Grand Causses Basin (van de Schootbrugge et al., 2010), where temperatures averaging approximately $18^{\circ} \mathrm{C}$ have been calculated. This warming interval is not so clearly marked in the brachiopod calcite of the Peniche section in Portugal (Suan et al., $2008,2010)$, but even very scattered $\delta^{18} \mathrm{O}$ values, and a peak palaeotemperature close to $30^{\circ} \mathrm{C}$, were frequently reported in the Cleveland Basin (Korte and Hesselbo, 2011). In the compilation made by Dera et al. $(2009,2011)$ and Martínez and Dera (2015), $\delta^{18} \mathrm{O}$ values are quite scattered, but this
Early Pliensbachian Warming interval is also well marked. Data on neodymium isotope presented by Dera et al. (2009) indicate the presence of a generalized southward current in the Euro-boreal waters for most of the Early Jurassic, except for the Early-Late Pliensbachian transition, where a positive $\varepsilon_{\mathrm{Nd}}$ excursion suggests a northward influx of warmer Tethyan or Panthalassan waters which could contribute to the seawater warming detected in the Early Pliensbachian.

\subsubsection{The Late Pliensbachian Cooling interval}

One of the most important Jurassic $\delta^{18} \mathrm{O}$ positive excursions is recorded in belemnites from the Late Pliensbachian to the Early Toarcian in all the correlated localities (Figs. 3, 7, 8). This represents a significant climate change towards cooler temperatures which begins at the base of the Late Pliensbachian and extends up to the earliest Toarcian Tenuicostatum Chronozone, representing a major cooling interval of around 4 Myrs. Average palaeotemperatures of $12.7^{\circ} \mathrm{C}$ for this period in the Rodiles section by assuming the absence of ice caps, and peak temperatures as low as $9.5^{\circ} \mathrm{C}$ were recorded in several samples from the Gibbosus and the Apyrenum subchronozones (Fig. 7).

This major cooling event has been recorded in many parts of the World. In Europe, the onset and the end of the cooling interval would appear to be synchronous at the scale of the ammonites subchronozone (Fig. 8). It starts in the Stokesi Subchronozone of the Margaritatus Chronozone (near the onset of the Late Pliensbachian), and extends up to the Early Toarcian Semicelatum Subchronozone of the Tenuicostatum Chronozone. In addition to the Asturian Basin (Gómez et al., 2008; Gómez and Goy, 2011; present paper), it has clearly been recorded in the Basque-Cantabrian Basin (Rosales et al., 2004; Gómez and Goy, 2011; García Joral et al., 2011) and in the Iberian Basin of Central Spain (Gómez et al., 2008; Gómez and Arias, 2010; Gómez and Goy, 2011), in the Cleveland Basin of the UK (McArthur et al., 2000; Korte and Hesselbo, 2011), in the Lusitanian Basin (Suan et al., 2008, 2010), in the French Grand Causses Basin (van de Schootbrugge et al., 2010), and in the data compiled by Dera et al. $(2009,2011)$.

As for many of the major cooling periods recorded in the Phanerozoic, low levels of atmospheric $p \mathrm{CO}_{2}$, and/or variations in oceanic currents associated with the break-up of Pangaea could explain these changes in seawater temperatures (Dera et al., 2009, 2011). The presence of relatively low $p \mathrm{CO}_{2}$ levels in the Late Pliensbachian atmosphere is supported by the value of $\sim 900$ ppm obtained from Pliensbachian araucariacean leaf fossils from southeastern Australia (Steinthorsdottir and Vajda, 2015). These values are much higher than the Quaternary preindustrial $280 \mathrm{ppm}$ $\mathrm{CO}_{2}$ measured (i.e. Wigley et al., 1996), but lower than the $\sim 1000$ ppm average estimated for the Early Jurassic. The Pliensbachian values recorded represent the minimum values of the Jurassic and of most of the Mesozoic, as documented 
by the GEOCARB II (Berner, 1994), and the GEOCARB III (Berner and Kothavala, 2001) curves, confirmed for the Early Jurassic by Steinthorsdottir and Vajda (2015). The causes of this lowering of atmospheric $p \mathrm{CO}_{2}$ are unknown but they might be favoured by elevated silicate weathering rates, nutrient influx, high primary productivity, and organic matter burial (Suan et al., 2010; Silva and Duarte, 2015). In addition, estimates of the mantle degassing based on the fit between the length of the subduction zones through time and the atmospheric $\mathrm{CO}_{2}$ levels (Van Der Meer et al., 2014), taking into account the standard GEOCARSULF degassing parameters (Berner, 2006a, b), suggests that plate tectonics has exerted a fundamental role in the control on the climatic system of the Earth.

The Late Pliensbachian appears to represent a time interval of major cooling, likely at global scale. This is why many authors point to this period as one of the main candidates for the development of polar ice caps in the Mesozoic (Price, 1999; Guex et al., 2001; Dera et al., 2011; Suan et al., 2011; Gómez and Goy, 2011; Fraguas et al., 2012). This idea is based on the presence, in the Upper Pliensbachian deposits of different parts of the World, of (1) glendonites; (2) exotic pebble to boulder-size clasts; (3) the presence in some localities of a hiatus in the Late Pliensbachian-earliest Toarcian; (4) the results obtained in the General Circulation Models, and (5) the Late Pliensbachian palaeotemperatures calculated and the assumed pole-to-equator temperature gradient.

\subsubsection{The Early Toarcian Superwarming interval}

Seawater temperature started to increase in the earliest Toarcian. From an average temperature of $12.7^{\circ} \mathrm{C}$ during the Late Pliensbachian Cooling interval, the average temperature rose to $15^{\circ} \mathrm{C}$ in the upper part of the earliest Toarcian Tenuicostatum Chronozone (Semicelatum Subchronozone), which represents a progressive increase in seawater temperature in the order of $2-3^{\circ} \mathrm{C}$. Atmospheric $\mathrm{CO}_{2}$ concentration during the Early Toarcian seems to have doubled from $\sim 1000$ to $\sim 2000$ ppm (i.e. Berner, 2006a, b; Retallack, 2009; Steinthorsdottir and Vajda, 2015), causing this intense and rapid warming. Comparison of the evolution of palaeotemperature with the evolution of the number of taxa reveals that progressive warming first coincides with a progressive loss of taxa by several groups (Gómez and Arias, 2010; Gómez and Goy, 2011; García Joral et al., 2011; Fraguas et al., 2012; Baeza-Carratalá et al., 2015) marking the prominent Early Toarcian extinction interval. Seawater palaeotemperature rapidly increased around the Tenuicostatum-Serpentinum zonal boundary, where average values of approximately $21^{\circ} \mathrm{C}$ were reached, with peak temperatures of $24^{\circ} \mathrm{C}$ (Fig. 7). This intense warming, which represents a $\Delta \mathrm{T}$ of around $8{ }^{\circ} \mathrm{C}$ with respect to the average temperatures of the Late Pliensbachian Cooling interval, coincides with the turnover of numerous groups (Gómez and Goy, 2011) the total disappearance of the brachiopods (García Jo- ral et al., 2011; Baeza-Carratalá et al., 2015), the extinction of numerous species of ostracods (Gómez and Arias, 2010), and a crisis of the nanoplankton (Fraguas, 2010; Fraguas et al., 2012; Clémence et al., 2015). Temperatures remain high and relatively constant during the Serpentinum and Bifrons chronozones, and the platforms were repopulated by opportunistic immigrant species that thrived in the warmer Mediterranean waters (Gómez and Goy, 2011).

\section{Conclusions}

Several relevant climatic oscillations across the Late Sinemurian, the Pliensbachian and the Early Toarcian have been documented in the Asturian Basin. The correlation of these climatic changes with other European records indicates that some of these might be at global scale. In the Late Sinemurian, a warm interval showing an average temperature of $18.5^{\circ} \mathrm{C}$ was recorded. The end of this warming interval coincides with the onset of a $\delta^{13} \mathrm{C}$ negative excursion that develops throughout the latest Sinemurian and part of the Early Pliensbachian.

The Late Sinemurian Warming interval is followed by a period of temperature averaging $16^{\circ} \mathrm{C}$, which develops during most of the Early Pliensbachian Jamesoni Chronozone as well as the base of the Ibex Chronozone. This temperature has been considered as the "normal" seawater palaeotemperature, because it coincides with the average temperature of the Late Sinemurian-Early Toarcian interval studied.

The latest part of the Early Pliensbachian is dominated by an increase in temperature, marking another warming interval which extends to the base of the Late Pliensbachian, where an average temperature of $18.2^{\circ} \mathrm{C}$ was calculated. Within this warming interval, a $\delta^{13} \mathrm{C}$ positive peak occurs at the transition between the Early Pliensbachian Ibex and the Davoei chronozones.

One of the most important climatic changes was recorded throughout the Late Pliensbachian. An average palaeotemperature of $12.7^{\circ} \mathrm{C}$ for this interval in the Rodiles section delineated a 4 Myrs major Late Pliensbachian Cooling event that was recorded in many parts of the World. At least in Europe, the onset and the end of this cooling interval is synchronous at the scale of the ammonites subchronozone. The cooling interval coincides with a $\delta^{13} \mathrm{C}$ slightly positive excursion, interrupted by a small negative $\delta^{13} \mathrm{C}$ peak in the latest Pliensbachian Hawskerense Chronozone. This prominent cooling event has been indicated as one of the main candidates for the development of polar ice caps in the Jurassic.

Seawater temperature started to increase in the earliest Toarcian, rising to $15^{\circ} \mathrm{C}$ in the latest Tenuicostatum Chronozone (Semicelatum Subchronozone), and seawater palaeotemperature showed a considerable increase around the Tenuicostatum-Serpentinum zonal boundary, reaching average values in the order of $21^{\circ} \mathrm{C}$, with peak intervals of $24^{\circ} \mathrm{C}$, which coincides with the Early Toarcian major extinc- 
tion event, pointing to warming as the main cause of the faunal turnover.

Acknowledgements. We thank three anonymous reviewers and the editor for their comments and suggestions that improved the manuscript. This research work was financed by project CGL201566604-R of the Spanish Ministerio de Economía y Competitividad, and by projects GR3/14/910431, and GI 910429 of the Universidad Complutense de Madrid. Thanks to the Instituto Geológico y Minero de España for allowing the use of the cathodoluminescence microscope.

Edited by: A. Sluijs

\section{References}

Al-Suwaidi, A. H., Angelozzi, G. N., Baudin, F., Damborenea, S. E., Hesselbo, S. P., Jenkyns, H. C., Manceñido, M. O., and Riccardi, A.C.: First record of the Early Toarcian Oceanic Anoxic Event from the Southern Hemisphere, Neuquén Basin, Argentina, J. Geol. Soc. London, 167. 633-636, 2010.

Anderson, T. F. and Arthur, M. A.: Stable isotopes of oxygen and carbon and their application to sedimentologic and paleoenvironmental problems, in: Stable isotopes in sedimentary geology, edited by: Arthur, M. A., SEPM Short Course 10, 1-1-1-151, 1983.

Anderson, T. F., Popp, B. N., Williams, A. C., Ho, L. Z., and Hudson, J. D.: The stable isotopic record of fossils from the Peterborough Member, Oxford Clay Formation (Jurassic), UK: palaeoenvironmental implications, J. Geol. Soc. London, 151, 125-138, 1994.

Armendáriz, M., Rosales, I., Bádenas, B., Aurell, M., GarcíaRamos, J. C., and Piñuela, L.: High-resolution chemostratigraphic record from Lower Pliensbachian belemnites: Palaeoclimatic perturbations, organic facies and water mass Exchange (Asturian basin, northern Spain), Palaeogeogr. Palaeocl., 333334, 178-191, 2012.

Bádenas, B, Aurell, M., García-Ramos, J. C., González, B., and Piñuela, L.: Sedimentary vs. Diagenetic control on rhytmic calcareous successions (Pliensbachian of Asturias, Spain), Terra Nova, 21, 162-170, 2009.

Bádenas, B, Aurell, M., Armendáriz, M., Rosales, I., GarcíaRamos, J. C., and Piñuela, L.: Sedimentary and chemostratigraphic record of climatic cycles in Lower Pliensbachian marllimestone platform successions of Asturias (North Spain), Sed. Geol., 281, 119-138, 2012.

Baeza-Carratalá, J. F., García Joral, F., Giannetti, A., and TentManclús, J. E.: Evolution of the last koninckinids (Athyrida, Koninckidae), a precursor signal of the early Toarcian mass extinction event in the Western Tethys, Palaeogeogr. Palaeocl., 429, 41-56, 2015.

Bailey, T. R., Rosenthal, Y., McArthur, J. M., van de Schootbrugge, B., and Thirlwall, M. F.: Paleoceanographic changes of the Late Pliensbachian-Early Toarcian interval: a possible link to the genesis of an Oceanic Anoxic event, Earth Planet. Sc. Lett., 212, 307-320, 2003.

Benito, M. I. and Reolid, M.: Belemnite taphonomy (Upper Jurassic, Western Tethys) part II: Fossil-diagenetic analysis includ- ing combined petrographic and geochemical techniques, Palaeogeogr. Palaeocl., 358-360, 89-108, 2012.

Berner, R. A.: GEOCARB II: A revised model of atmospheric $\mathrm{CO}_{2}$ over Phanerozoic time, Am. J Sci. 249, 56-41, 1994.

Berner, R. A.: GEOCARBSUL: a combined model for Phanerozoic atmospheric $\mathrm{O}_{2}$ and $\mathrm{CO}_{2}$, Geochim. Cosmochim. Ac., 70, 56535664, 2006a.

Berner, R. A: Inclusion of the weathering of volcanic rocks in the GEOCARBSULF Model, Am. J. Sci., 306, 295-302, 2006b.

Berner, R. A. and Kothavala, Z.: GEOCARB III. A revised model of atmospheric $\mathrm{CO}_{2}$ over Phanerozoic time, Am. J. Sci., 301, 182-204, 2001.

Bettencourt, V. and Guerra, A.: Carbon- and Oxygen-isotope composition of the cuttlebone of Sepia officialis: a tool for predicting ecological information, Mar. Biol., 133, 651-657, 1999.

Bodin, S., Mattioli, E., Fröhlich, S., Marshall, J. D., Boutib, L., Lahsini, S., and Redfern, J.: Toarcian carbon isotope shifts and nutrient changes from the Northern margin of Gondwana (High Atlas, Morocco, Jurassic): Palaeoenvironmental implications, Palaeogeogr. Palaeocl., 297, 377-390, 2010.

Caruthers, A. W., Smith, P. L., and Gröcke, D. R.: The Pliensbachian-Toarcian (Early Jurassic) extinction: A North American perpestive, in: Volcanism, Impacts and Mass Extinctions: Causes and Effects, edited by: Keller, G. and Kerr, A. C., Geo. Soc. Am. Spec. Paper, 505, 225-243, 2014.

Chandler, M. A., Rind, D., and Ruedy, R.: Pangaean climate during the Early Jurassic: GCM simulations and the sedimentary record of paleoclimate, Geol. Soc. Am. Bull., 104, 543-559, 1992.

Clémence, M. E.: Pattern and timing of the Early Jurassic calcareous nannofossil crisis, Palaeogeogr. Palaeocl., 411, 56-64, 2014.

Clémence, M. E., Gardin, S., and Bartolini A.: New insights in the pattern and timing of the Early Jurassic calcareous nannofossil crisis, Palaeogeogr. Palaeocl., 427, 100-108, 2015.

Cohen, A. S., Coe, A. L., Harding, S. M., and Schwark, L.: Osmium isotope evidence for regulation of atmospheric $\mathrm{CO}_{2}$ by continental weathering, Geology, 32, 157-160, 2004.

Comas-Rengifo, M. J.: El Pliensbachiense de la Cordillera Ibérica, PhD Universidad Complutense de Madrid, 1982, Col. Tes. Doct. UCM 19/85, 1-591, 1985.

Comas-Rengifo, M. J. and Goy, A.: Caracterización biocronoestratigráfica del Sinemuriense Superior y el Pliensbachiense entre los afloramientos de Playa de Vega y de Lastres (Asturias), in: Las sucesiones margo-calcáreas marinas del Jurásico Inferior y las series fluviales del Jurásico Superior. Acantilados de Playa de Vega (Ribadesella), edited by: García-Ramos, J. C. (Coord.), V Congreso Jurásico de España, MUJA, 9-18, 2010.

Dera, G., Pucéat, E., Pellenard, P., Neige, P., Delsate, D., Joachimski, M. M., Reisberg, L., and Martinez, M.: Water mass exchange and variations in seawater temperature in the NW Tethys during the Early Jurassic: Evidence from neodymium and oxygen isotopes of fish teeth and belemnites, Earth. Planet. Sc. Lett., 286, 198-207, 2009.

Dera, G., Neige, P., Dommergues, J. L., Fara, E., Lafont, R., and Pellenard, P.: High-resolution dynamics of Early Jurassic marine extinctions: the case of Pliensbachian-Toarcian ammonites (Cephalopoda), J. Geol. Soc. London, 167, 21-33, 2010.

Dera, G., Brigaud, B., Monna, F., Laffont, R., Pucéat, E., Deconinck, J. F., Pellenard, P., Joachimski, M. M., and Durlet, C.: Cli- 
matic ups and downs in a disturbed Jurassic world, Geology, 39, 215-218, 2011.

Dommergues, J.-L., Meister, C., and Mouterde, R.: Pliensbachien. Bioestratigraphie du Jurassique ouest-européen et méditerranéen: zonations parallèles et distribution des invertébrés et microfossils, edited by: Cariou, E. and Hantzpergue, P., Bull. Centre Rech. Elf Explor. Prod., Pau, 17, 15-24, 1997.

Elmi, S., Rulleau, L., Gabilly, J., and Mouterde, R.: Toarcien. Bioestratigraphie du Jurassique ouest-européen et méditerranéen: zonations parallèles et distribution des invertébrés et microfossils, edited by: Cariou, E. and Hantzpergue, P., Bull. Centre Rech. Elf Explor. Prod., Pau, 17, 25-36, 1997.

Fraguas, A.: Late Sinemurian-Early Toarcian calcareous nannofosils from the Cantabrian Basin: spatial and temporal distribution, $\mathrm{PhD}$ thesis, Fac. Sci. Geol. Univ. Complutense Madrid, Spain, 2010.

Fraguas, A., Comas-Rengifo, M. J., Gómez, J. J., and Goy, A.: The calcareous nannofossil crisis in Northern Spain (Asturias province) linked to the Early Toarcian warming-driven mass extinction, Mar. Micropaleontol., 94-95, 58-71, 2012.

Frakes, L. A., Francis, J. E., and Syktus, J. I.: Climate models of the Phanerozoic, Cambridge University Press, Cambridge, 274 pp, 1992.

Francheschi, M., Dal Corso, J., Posenato, R., Roghi, Masetti, D., and Jenkyns, H. C.: Early Pliensbachian (Early Jurassic) Cisotope perturbation and the diffusion of the Lithiotis Fauna: Insights from the western Tethys, Palaeogeogr. Palaeocl., 410, 255-263, 2014.

García Joral, F., Gómez, J. J., and Goy, A.: Mass extinction and recovery of the Early Toarcian (Early Jurassic) brachiopods linked to climate change in northern and central Spain, Palaeogeogr. Palaeocl., 302, 367-380, 2011.

Gómez, J. J. and Arias, C.: Rapid warming and ostracods mass extinction at the Lower Toarcian (Jurassic) of central Spain, Mar. Micropaleontol., 74, 119-135, 2010.

Gómez, J. J. and Goy, A.: Warming-driven mass extinction in the Early Toarcian (Early Jurassic) of northern Spain. Correlation with other time-equivalent European sections, Palaeogeogr. Palaeocl., 306, 176-195, 2011.

Gómez, J. J., Goy, A., and Canales, M. L.: Seawater temperature and carbon isotope variations in belemnites linked to mass extinction during the Toarcian (Early Jurassic) in Central and Northern Spain. Comparison with other European sections, Palaeogeogr. Palaeocl., 258, 28-58, 2008.

Goy, A., Comas-Rengifo, M. J., García-Ramos, J. C., Gómez, J. J., Herrero, C., Suárez-Vega, L. C., and Ureta, M.: The Toarcian Stage in Asturias (North Spain): Ammonites record, stratigraphy and correlations, Earth Sci. Frontiers, Spec. Publ., 17, 38-39, 2010a.

Goy, A., Comas-Rengifo, M. J., Gómez, J. J., Herrero, C., SuárezVega, L. C., and Ureta, M.: Biohorizontes de ammonoideos del Toarciense en Asturias, edited by: Ruiz Omeñaca, J. J., Piñuelas, L., and García-Ramos, J. C., Com. V Congreso Jurásico de España, MUJA, 94-102, 2010b.

Guex, J., Morard, A., Bartolini, A., and Morettini, E.: Découverte d'une importante lacune stratigraphique à la limite DomérienToarcien: implications paléo-océnographiques, Bull. Soc. Vaud. Sc. Nat., 87, 277-284, 2001.
Hallam, A.: Jurassic environments, Cambridge Earth Sci. Ser., Cambridge University Press, Cambridge, 269 pp., 1975.

Hallam, A.: Jurassic climates as inferred from the sedimentary and fossil record, Philos. T. R. Soc. B, 342, 287-296, 1993.

Harazim, D., van de Schootbrugge, B., Sorichter, K., Fiebig, J., Weug, A., Suan, G., and Oschmann, W.: Spatial variability of watermass conditions within the European Epicontinental Seaway during the Early Jurassic (Pliensbachian-Toarcian), Sedimentology, 60, 359-390, 2013.

Hesselbo, S. P., Gröcke, D. R., Jenkyns, H. C., Bjerrum, C. J., Farrimond, P., Morgans Bell, H. S., and Green, O. R.: Massive dissociation of gas hydrate during a Jurassic oceanic anoxic event, Nature, 406, 392-395, 2000.

Hesselbo, S. P., Meister, C., and Gröcke, D. R.: A potential global stratotype for the Sinemurian-Pliensbachian-boundary (Lower Jurassic), Robin Hood's Bay, UK; ammonite faunas and isotope stratigraphy, Geol. Mag., 137, 601-607, 2000.

Hesselbo, S. P., Jenkyns, H. C., Duarte, L. V., and Oliveira, L. C. V.: Carbon-isotope record of the Early Jurassic (Toarcian) Oceanic Anoxic Event from fossil wood and marine carbonate (Lusitanian Basin, Portugal), Earth Planet. Sc. Lett., 253, 455-470, 2007.

Howarth, M. K.: The Lower Lias of Robin Hood's Bay, Yorkshire, and the work of Leslie Bairstow, Bull. br. Mus. nat. Hist. Geol., 58, 81-152, 2002.

Ikeda, M. and Tada, R.: Long period astronomical cycles from the Triassic to Jurassic bedded chert sequence (Inuyama, Japan): Geologic evidences for the chaotic behaviour of solar planets, Earth Planets Space, 65, 351-360, 2013.

Ikeda, M. and Tada, R.: A 70 million year astronomical time scale for the deep-sea bedded chert sequence (Inuyama, Japan): Implications for Triassic-Jurassic geochronology. Earth. Planet. Sc. Lett., 399, 30-43, 2014.

Jenkyns, H. C.: Evidence for rapid climate change in the MesozoicPalaeogene greenhouse world, Philos. T. R. Soc. A, 361, 18851916, 2003.

Jenkyns, H. C. and Clayton, C. J.: Lower Jurassic epicontinental carbonates and mudstones from England and Wales: chemostratigraphic signals and the early Toarcian anoxic event, Sedimentology, 44, 687-706, 1997.

Jenkyns, H. C. and Weedon, G. P.: Chemostratigraphy $\left(\mathrm{CaCO}_{3}\right.$, TOC, $\delta^{13} \mathrm{C}_{\text {org }}$ ) of Sinemurian (Lower Jurassic) black shales from the Wessex Basin, Dorset and palaeoenvironmental implications, Newsl. on Stratigr., 46, 1-21, 2013.

Jenkyns, H. C., Jones, C. E., Gröcke, D. R., Hesselbo, S. P., and Parkinson, D. N.: Chemostratigraphy of the Jurassic System: application, limitations and implications for palaeoceanography, J. Geol. Soc. London, 159, 351-378, 2002.

Kemp, D. B., Coe, A. L., Cohen, A. S., and Schwark, L.: Astronomical pacing of methane release in the Early Jurassic period, Nature 437, 396-399, 2005.

Kidder, D. L. and Worsley, T. R., Phanerozoic Large Igneous Province (LIPs): HEATT (Haline Euxinic Acidic Thermal Transgression) episodes, and mass extinctions, Palaeogeogr. Palaeocl., 295, 162-191, 2010.

Korte, C. and Hesselbo, S. P.: Shallow marine carbon and oxygen isotope and elemental records indicate icehouse-greenhouse cycles during the Early Jurassic, Paleoceanography, 26, PA 4219, doi:10.1029/2011PA002160, 2011. 
Kump, L. R. and Arthur, M. A.: Interpreting carbon-isotope excursions: carbonates and organic matter, Chem. Geol., 161, 181198, 1999.

Li, Q., McArthur, J. M., and Atkinson, T. C.: Lower Jurassic belemnites as indicators of palaeo-temperature, Palaeoclimatol. Palaeoecol., 315-316, 38-45, 2012.

Littler, K., Hesselbo, S. P., and Jenkyns, H. C.: A carbon-isotope perturbation at the Pliensbachian-Toarcian boundary: evidence from the Lias Group, NE England, Geol. Mag., 147, 181-192, 2010.

Martinez, M. and Dera, G.: Orbital pacing of carbon fluxes by a $\sim 9-$ My eccentricity cycle during the Mesozoic, P. Natl. Acad. Sci. USA, 112, 12604-12609, 2015.

McArthur, J. M., Donovan, D. T., Thirlwall, M. F., Fouke, B. W., and Mattey, D.: Strontium isotope profile of the early Toarcian (Jurassic) oceanic anoxic event, the duration of ammonite biozones, and belemnite palaeotemperatures, Earth. Planet. Sc. Lett., 179, 269-285, 2000.

McArthur, J. M., Doyle, P., Leng, M. J., Reeves, K., Williams, T., García-Sanchez, R., and Howart, R. J.: Testing palaeoenvironmental proxies in Jurassic belemnites: $\mathrm{Mg} / \mathrm{Ca}, \mathrm{Sr} / \mathrm{Ca}$, $\mathrm{Na} / \mathrm{Ca}, \delta^{18} \mathrm{O}$ and $\delta^{13} \mathrm{C}$, Palaeogeogr. Palaeocl., 252, 464-480, 2007.

McElwain, J. C., Wade-Murphy, J., and Hesselbo, S. P.: Changes in carbon dioxide during an oceanic anoxic event linked to intrusion into Gondwana coals, Nature, 435, 479-482, 2005.

Metodiev, L. and Koleva-Rekalova, E.: Stable isotope records $\left(\delta^{18} \mathrm{O}\right.$ and $\delta^{13} \mathrm{C}$ ) of Lower-Middle Jurassic belemnites from the Western Balkan mountains (Bulgaria): Palaeoenvironmental application, Appl. Geochem., 23, 2845-2856, 2008.

Mitchell, S. F.: Eight belemnite biohorizons in the Cenomanioan of northwest Europe and their importance, Geol. J., 40, 363-382, 2005 .

Morettini, E., Santantonio, M.; Bartolini, A., Cecca, F., Baumgartner, P. O., and Hunziker, J. C.: Carbon isotope stratigraphy and carbonate production during the Early-Middle Jurassic: examples from the Umbria-Marche-Sabina Apennines (central Italy), Palaeogeogr. Palaeocl., 184, 251-273, 2002.

Mutterlose, J., Malkoc, M., Schouten, S., Sinninghe Damsté, J. S., and Foster, A.: TEX $_{86}$ and stable $\delta^{18} \mathrm{O}$ paleothermometry of early Cretaceous sediments: Implications for belemnite ecology and palaeotemperature proxy application, Earth Planet. Sc. Lett., 298, 286-298, 2010.

Nikitenko, B. L.: The Early Jurassic to Aalenian paleobiogeography of the arctic realm: Implication of microbenthos (foraminifers and ostracodes), Stratigr. Geol. Correl., 16, 59-80, 2008.

Ogg, J. G. and Hinnov, L. A.: The Geologic Time Scale 2012, Chapter 26, Jurassic, 731-791, 2012.

Osete, M. L., Gómez, J. J., Pavón-Carrasco, F. J., Villalaín, J. J., Palencia, A., Ruiz-Martínez, V. C., and Heller, F.: The evolution of Iberia during the Jurassic from palaeomagnetic data, Tectonophysics, 50, 105-120, 2010.

Page, K. N.: The Lower Jurassic of Europe: its subdivision and correlation, Geol. Survey Denmark and Greeland Bull., 1, 23-59, 2003

Payne, J. L. and Kump, L. R.: Evidence for recurrent Early Triassic massive volcanism from quantitative interpretation of carbon isotope fluctuations, Earth Planet. Sc. Lett., 256, 264-277, 2007.
Phelps, M. C.: A refined ammonite biostratigraphy for the Middle and Upper Carixian (Ibex and Davoei zones, Lower Jurassic) in North-West Europe and stratigraphical details of the CarixianDomerian boundary, Geobios, 18, 321-362, 1985.

Price, G. D.: The evidence of polar ice during the Mesozoic, Earth Sci. Rev., 48, 183-210, 1999.

Price, G. D., Twitchett, R. J., Smale, C., and Marks, V.: Isotopic analysis of the life history of the enigmatic squid Spirula spirula, with implications for studies of fossil cephalopods, Palaios, 24, 273-279, 2009.

Prokoph, A., Shields, G. A., and Veizer, J.: Compilation and timeseries analysis of a marine carbonate $\delta^{18} \mathrm{O}, \delta^{13} \mathrm{C},{ }^{87} \mathrm{Sr} /{ }^{86} \mathrm{Sr}$ and $\delta^{34} \mathrm{~S}$ database through Earth history, Earth Sci. Rev., 87, 113133, 2013.

Quesada, S., Robles, S., and Rosales, I.: Depositional architecture and transgressive-regressive cycles within Liassic backstepping carbonate ramps in the Basque-Cantabrian Basin, northern Spain, J. Geol. Soc. London, 162, 531-548, 2005.

Rees, P. A., Zeigler, A. M., and Valdes, P. J.: Jurassic phytogeography and climates: new data and model comparisons, in: Warm climates in Earth History, edited by: Huber, B., Macleod, K., and Wing, S., Cambridge University Press, Cambridge, 297-318, 1999.

Retallack, G. J.: Greenhouse crises of the past 300 million years, Geol. Soc. Am. Bull., 121, 1441-1455, 2009.

Rexfort, A. and Mutterlose, J.: The role of biogeography and ecology on the isotope signature of cuttlefishes (Cephalopoda, Sepiidae) and the impact on belemnite studies, Palaeogeogr. Palaeocl., 244, 212-221, 2009.

Röhl, H. J., Schmid-Röhl, A., Oschmann, W., Frimmel, A., and Schwark, L.: The Posidonia Shale (Lower Toarcian) of SWGermany: an oxygen-depleted ecosystem controlled by sea level and palaeoclimate, Palaeogeogr. Palaeocl., 165, 27-52, 2001.

Rosales, I., Quesada, S., and Robles, S.: Primary and diagenetic isotopic signal in fossils and hemipelagic carbonates: the lower Jurassic of northern Spain, Sedimentology, 48, 1149-1169, 2001.

Rosales, I., Quesada, S., and Robles, S.: Paleotemperature variations of Early Jurassic seawater recorded in geochemical trends of belemnites from the Basque-Cantabrian basin, northern Spain, Palaeogeogr. Palaeocl., 203, 253-275, 2004.

Sælen, G., Doyle, P., and Talbot, M. R.: Stable-Isotope Analyses of Belemnite Rostra from the Whitby Mudstone Fm., England: Surface Water Conditions during Deposition of a Marine Black Shale, Palaios, 11, 97-117, 1996.

Schmid-Röhl, A., Röhl, H.J., Oschmann, W., Frimmel, A., and Schwark, L.: Palaeoenvironmental reconstruction of Lower Toarcian epicontinental black shales (Posidonia Shale, SW Germany): global versus regional control, Geobios, 35, 13-20, 2002.

Schouten, S., van Kaam-Peters, H. M. E., Rijpstra, W. I. C., Schoell, M., and Sinninghe Damste, J. S.: Effects of an oceanic anoxic event on the stable carbon isotopic composition of Early Toarcian carbon, Am. J. Sci., 300, 1-22, 2000.

Shackleton, N. J. and Kenett, J. P.: Paleotemperature history of the Cenozoic and the initiation of Antarctic glaciation: Oxygen and carbon isotope analysis in DSDP sites 277, 279 and 281, in: Initial Reports of the Deep Sea Drilling Projects, 29, edited by: Kennet, J. P., Houtz, R. E., Andrews, P. B., Edwards, A. R., Gosting, V. A., Hajós, M., Hampton, M. A., Jenkins, D. G., Margolis, 
S. V., Ovenshine, A. T., and Perch-Nielsen, K., US Government Printing Office, Washington, 743-756, 1975.

Silva, R. L., Duarte, L. V., Comas-Rengifo, M. J., Mendonça Filho, J. G., and Azerêdo, A. C.: Update of the carbon and oxygen isotopic records of the Early-late Pliensbachian (Early Jurassic, $\sim 187 \mathrm{Ma}$ ): insights from the organic-rich hemipelagic series of the Lusitanian Basin (Portugal), Chem. Geol., 283, 177-184. 2011.

Silva, R. L. and Duarte, L. V.: Organic matter production and preservation in the Lusitanian Basin (Portugal) and Pliensbachian climatic snaps, Global and Planet. Change, 131, 24-34, 2015.

Steinthorsdottir, M. and Vajda, V.: Early Jurassic (late Pliensbachian) $\mathrm{CO}_{2}$ concentrations based on stomatal analysis of fossil conifer leaves from eastern Australia, Gondwana Res., 27, 829897, 2015.

Suan, G., Mattioli, E., Pittet,B., Maillot, S., and Lécuyer, C.: Evidence for major environmental perturbation prior to and during the Toarcian (Early Jurassic) Oceanic Anoxic Event from the Lusitanian Basin, Portugal, Paleoceanography 23, 1202, doi:10.1029/2007PA001459, 2008.

Suan, G., Mattioli, E., Pittet,B., Lécuyer, C., Suchéras-Marx, B., Duarte, L. V., Philippe, M., Reggiani, F., and Martineau, F.: Secular environmental precursor to Early Toarcian (Jurassic) extreme climate changes, Earth Planet. Sc. Lett., 290, 448-458, 2010.

Suan, G., Nikitenko, B., Rogov, M. A., Baudin, F., Spangenberg, J. E., Knyazev, V. G., Glinskikh, L. A., Goryacheva, A. A., Adatte, T., Riding, J., Föllmi, K. B., Pittet, B.,Mattioli, E., and Lécuyer, C.: Polar record of Early Jurassic massive carbon injection, Earth Planet. Sc. Lett., 312, 102-113, 2011.

Suárez-Vega, L. C.: Estratigrafía del Jurásico en Asturias, Cuad. Geol. Ibérica, 3, 1-369, 1974.

Svensen, H., Planke, S., Chevalier, L., Malthe-Sørenssen, A., Corfu, F., and Jamtveit, B.: Hydrothermal venting of greenhouse gasses triggering Early Jurassic global warming, Earth Planet. Sc. Lett., 256, 554-566, 2007.

Ullmann, C. V. and Korte, C.: Diagenetic alteration in low-Mg calcite from macrofossils: a review, Geol. Q., 59, 3-20, 2015.

Ullmann, C. V., Thibault, N., Ruhl, M., Hesselbo, S. P., and Korte, C.: Effect of a Jurassic oceanic anoxic event on belemnite ecology and evolution, P. Natl. Acad. Sci. USA, 111, 10073-10076, 2014.
Valenzuela, M.: Estratigrafía, sedimentología y paleogeografía del Jurásico de Asturias, PhD Thesis, Fac. Sci. Geol. Univ. Oviedo, Spain, 1988.

Van Der Meer, D. G., Zeebec, R. E., van Hinsbergena, D. J. J., Sluijs, A., Spakmana, W., and Torsvik, T. H.: Plate tectonic controls on atmospheric $\mathrm{CO}_{2}$ levels since the Triassic, PNAS, 111, 12, 4380-4385, doi:10.1073/pnas.1315657111, 2014.

Van Hinsbergen, D. J. J., de Groot L. V., van Schaik S. J., Spakman W., Bijl P. K., Sluijs A., Langereis, C. G., and Brinkhuis, H.: A Paleolatitude Calculator for Paleoclimate Studies. PLoS ONE 10, e0126946. doi:10.1371/journal.pone.0126946, 2015.

van de Schootbrugge, B., Harazim, D., Sorichter, K., Oschmann, W., Fiebig, J., Püttmann, W., Peinl, M., Zanella, F., Teichert, B. M. A., Hoffmann, J., Stadnitskaia, A., and Rosenthal, Y.: The enigmatic ichnofossil Tisoa siphonalis and widespread authigenic seep carbonate formation during the Late Pliensbachian in southern France, Biogeosciences, 7, 3123-3138, doi:10.5194/bg7-3123-2010, 2010.

Wierzbowski, H. and Joachimski, M. M.: Reconstruction of Late Bajocian-Bathonian marine palaeoenvironments using carbon and oxygen isotope ratios of calcareous fossils from the Polish Jura Chain (central Poland), Palaeogeogr. Palaeocl., 254, 523540, 2007.

Wigley, T. M. L., Richels, R., and Edmonds, J. A.: Economic and environmental choices in the stabilization of atmospheric $\mathrm{CO}_{2}$ concentrations, Nature, 379, 240-243, 1996.

Woodfine, R. G., Jenkyns, H. C., Sarti, M., Baroncini, F., and Violante, C.: The response of two Tethyan carbonate platforms to the early Toarcian (Jurassic) oceanic anoxic event: environmental change and differential subsidence, Sedimentology, 55, 10111028, 2008.

Zakharov, V. A., Shurygin, B. N., Il'ina, V. I., and Nikitenko, B. L.: Pliensbachian-Toarcian biotic turnover in North Siberia and the Artic Region, Stratigr. Geol. Correl., 14, 399-417, 2006. 